SJ Quinney College of Law, University of Utah Utah Law Digital Commons

Utah Law Faculty Scholarship

Utah Law Scholarship

6-2019

\title{
Dealing with Climate Change Under the National Environmental Policy Act
}

Arnold W. Reitze Jr.

S.J. Quinney College of Law, University of Utah, arnold.reitze@law.utah.edu

Follow this and additional works at: https://dc.law.utah.edu/scholarship

Part of the Environmental Law Commons

\section{Recommended Citation}

Reitze, Arnold W. Jr., "Dealing with Climate Change Under the National Environmental Policy Act" (2019). Utah Law Faculty Scholarship. 165.

https://dc.law.utah.edu/scholarship/165

This Article is brought to you for free and open access by the Utah Law Scholarship at Utah Law Digital Commons. It has been accepted for inclusion in Utah Law Faculty Scholarship by an authorized administrator of Utah Law Digital Commons. For more information, please contact valeri.craigle@law.utah.edu. 


\title{
Dealing With Climate Change Under the National Environmental Policy ACt
}

\author{
ARNOLD W. REITZE, JR. *
}

ABSTRACT

The National Environmental Policy Act ("NEPA") was an important environmental law for several decades before climate change became an issue of concern. In the 1990s, efforts began to include in NEPA's environmental assessments and environmental impact statements both the impact of federal government actions on climate change and the impact of climate change on proposed federal actions. These efforts were encouraged by the Council on Environmental Quality (“CEQ"). However, implementation at the agency level has since been uneven. Some federal agencies have resisted making serious efforts to incorporate climate change impacts into their decision-making process. Moreover, the courts have not been consistent in their reviews of agency compliance with NEPA, and the judiciary often gives substantial deference to an agency's minimal NEPA compliance. Since 2017, determining NEPA's requirements for climate change analysis has become more challenging because the Trump administration is changing federal environmental policies and regulations in order to encourage fossil fuel energy development and use, which will increase the emissions of greenhouse gases ("GHG").

I. INTRODUCTION TO NEPA . . . . . . . . . . . . . . . 174

A. Reasonable Alternatives ................ 178

B. Mitigation..................... 179

II. THE CEQ's GUIDANCE CONCERNING THE APPLICATION OF NEPA to Climate Change . . . . . . . . . . . . . . . . . . . . . 180

III. The White House Proposal to Streamline

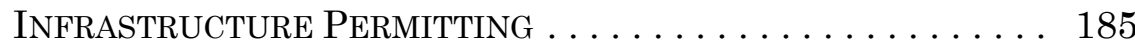

IV. Executive ORders Related to Climate Change. . . . . . 187

\footnotetext{
* Professor of Law, S.J. Quinney College of Law, The University of Utah. Member of the Utah Air Quality Board. Research assistance was provided by JD candidate Angeline Portel. This research was supported by the Albert and Elaine Borchard Fund for Faculty Excellence. arnold.reitze@law.utah.edu.
} 
V. SPECIFIC AGEnCy NEPA REgulations . . . . . . . . . . . 192

A. $\quad$ The Department of Energy's NEPA Regulations . . . 192

B. The Department of the Interior and its BLM NEPA

Requirements .................... 193

C. The EPA's NEPA Requirements. . .......... 196

VI. NEPA Litigation InVolving Climate Change Issues. . . 197

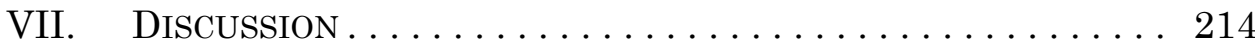

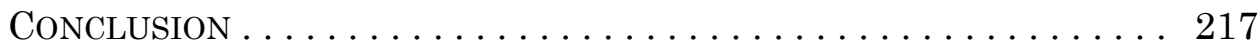

\section{INTRODUCTION TO NEPA}

The NEPA was the first important environmental statute enacted in the decade of the 1970s when it was signed into law on January 1, $1970 .{ }^{1}$ Unlike the long and complex statutes dealing with air pollution, water pollution, and hazardous material that would later be enacted, NEPA at that time was a five-page statute and the important part of the Act was one section: $102(2)(\mathrm{C}){ }^{2}$ This section requires "every recommendation or report on proposals for legislation and other major Federal actions significantly affecting the quality of the human environment" to include "a detailed [environmental impact] statement [("EIS")] by the responsible official." ${ }^{3}$ This action-forcing provision requires an environmental impact statement that includes:

(i.) the environmental impact of the proposed action,

(ii.) any adverse environmental effects which cannot be avoided should the proposal be implemented,

(iii.) alternatives to the proposed action,

(iv.) the relationship between local short-term uses of man's environment and the maintenance and enhancement of long-term productivity, and

(v.) any irreversible and irretrievable commitments of resources which would be involved in the proposed action should it be implemented. ${ }^{4}$

\footnotetext{
${ }^{1}$ National Environmental Policy Act of 1969, Pub. L. No. 91-190, § 102, 83 Stat. 852 (1970) [hereinafter NEPA] (codified as amended at 42 U.S.C. $§ \S 4331-4370 \mathrm{~h}(2017)$ ).

${ }^{2} I d$.

${ }^{3} I d$. at 853 .

${ }^{4} I d$.
} 
This important provision has almost no legislative history. ${ }^{5}$ Moreover, the legislation initially provided almost no funding, and it failed to provide for staff to implement the law. ${ }^{6}$ Congress subsequently added Title II to the Federal Water Pollution Control amendments of 1970, which authorized staff for the CEQ. ${ }^{7}$ The deficiencies of NEPA would have prevented it from being effective, except for the decisions of the federal courts in the 1970s that provided the elements needed to make the statute a useful tool. ${ }^{8}$ The courts allowed conservation groups to enforce the law by recognizing their standing based on "federal question" jurisdiction. ${ }^{9}$ While NEPA does not provide a private right of action, the courts review the actions of federal agencies as final agency actions that can be reviewed based on Section 209 of the Administrative Procedure Act ("APA"). ${ }^{10}$ Jurisdiction is in the federal district courts, and nonfederal litigants can participate in NEPA cases. ${ }^{11}$ Although the statute provides no sanctions, federal courts in the 1970s issued injunctions that prevented projects from going forward when there was a failure to comply with NEPA. ${ }^{12}$ The lack of a budget large enough to implement NEPA was solved by shifting most of the cost of compliance to the proponent of a project. ${ }^{13}$ Regulations found at 40 C.F.R. Parts 1500-1508, discussed infra, have fleshed out the requirements found in the statute.

The first step in the NEPA process is usually to prepare an Environmental Assessment ("EA") to determine whether a more comprehensive EIS is required. ${ }^{14} \mathrm{~A}$ draft EA may be produced by an applicant, a state, or a consulting firm, but the responsibility for producing the EA is imposed on the lead federal agency. ${ }^{15}$ The EA "[s]hall include brief

\footnotetext{
${ }^{5}$ See S.1075; H.R. 6750, 91st Cong. (1969).

${ }^{6}$ See generally id.

${ }^{7}$ Environmental Quality Improvement Act of 1970, Pub. L. No. 91-224, § 202(c)(2), 84 Stat. 114, 114 (1970).

${ }^{8}$ See cases cited infra note 10 .

${ }^{9}$ See 28 U.S.C. $\$ 1331$ (2012).

${ }^{10}$ See Japan Whaling Ass'n v. Am. Cetacean Soc'y, 478 U.S. 221, 230 n.4 (1986); Duke Power Co. v. Carolina Study Group, Inc., 438 U.S. 59, 71 (1978); Calvert Cliffs' Coordinating Comm., Inc. v. U.S. Atomic Energy Comm'n, 449 F.2d 1109, 1128-29 (D.C. Cir. 1971).

${ }^{11}$ See, e.g., Wilderness Soc'y v. U.S. Forest Serv., 630 F.3d 1173, 1180-81 (9th. Cir. 2011).

${ }^{12}$ See, e.g., Wilderness Soc'y v. Morton, 479 F.2d 842, 887-93 (D.D.C. 1973) (enjoining the Department of Interior from issuing a permit needed to construct the Trans-Alaska Pipeline); N. Cheyenne Tribe v. Norton, 503 F.3d 836, 841 (9th Cir. 2007).

${ }^{13}$ See generally NEPA, 42 U.S.C. $\S \S 4331-4370 h$ (2017).

${ }^{14} 40$ C.F.R. $\S 1501.4($ b) - (c) (2018).

${ }^{15}$ See, e.g., Cachil Dehe Band of Wintun Indians of the Colusa Indian Community v. Zinke, 889 F.3d 584, 600-03, 607 (9th Cir. 2018).
} 
discussions of the need for the proposal, of alternatives as required by section 102(2)(E), of the environmental impacts of the proposed action and alternatives, and a listing of agencies and persons consulted." 16

If the agency's EA concludes the proposed action has no significant impact on the environment, it can choose not to prepare an EIS by issuing a finding of no significant impact ("FONSI"). ${ }^{17}$ The D.C. Circuit uses a four-part test to determine the validity of a FONSI.$^{18}$ The court will determine: (1) whether the agency took a "hard look" at the proposal; (2) whether "the relevant areas of environmental concern" were addressed; (3) whether the agency made a convincing determination that the environmental impact was insignificant; and (4) if the impact is significant, whether the changes in the proposed project will sufficiently reduce the adverse environmental impact. ${ }^{19}$ NEPA's requirements must be met before a federal agency makes "any irreversible and irretrievable commitment of resources." ${ }^{20}$ If an EIS is required, a Draft EIS ("DEIS") is prepared, which leads to a Final EIS ("FEIS"). ${ }^{21}$ This is followed by a Record of Decision ("ROD") that identifies alternatives considered, as well as the relevant factors considered by the agency and the mitigation, monitoring, and enforcement measures selected. ${ }^{22}$

NEPA requires federal agencies to promulgate their own regulations to comply with the Act, including identifying actions that normally require an EA or an EIS and those that do not. ${ }^{23}$ The Department of Energy promulgated its regulations on April 24, 1992. ${ }^{24}$ The Department of the Interior's regulations are found in its department manual. ${ }^{25}$ U.S. Forest Service regulations are found at 36 C.F.R. $220 .{ }^{26}$ The Environmental Protection Agency ("EPA") is treated differently than the other federal

\footnotetext{
${ }^{16} 40$ C.F.R. $\S 1508.9(b)(2018)$.

${ }^{17} 40$ C.F.R. $\S 1501.4(\mathrm{e})(2018)$.

${ }^{18}$ Sierra Club v. Peterson, 717 F.2d 1409, 1413 (D.C. Cir. 1983).

${ }^{19} I d$.

${ }^{20}$ Metcalf v. Daley, 214 F.3d 1135, 1143 (9th Cir. 2000) (quoting Conner v. Burford, 848 F.2d 1441, 1446 (9th Cir. 1988)).

${ }^{21} 40$ C.F.R. $\S \S 1502.4,1502.9$ (2018).

${ }^{22} 40$ C.F.R. $\S 1505.2(2018)$.

${ }^{23} 40$ C.F.R. $\S 1507.3(\mathrm{~b})(2)(\mathrm{i})-(\mathrm{iii})$ (2018).

${ }^{24}$ NEPA Implementing Procedures, 57 Fed. Reg. 15,122 (Apr. 24, 1992) (codified as amended at 10 C.F.R. pt. 1021); 61 Fed. Reg. 64,603 (Dec. 6, 1996) (codified as amended at 10 C.F.R. pt. 1021).

${ }^{25}$ Departmental Manual, U.S. DEP’T OF INTERIOR at pt. 516 (2009), http://elips.doi.gov/elips /browse.aspx [https://perma.cc/UX4E-TRFW] (follow "Department Manual" folder hyperlink). BLM's regulations were promulgated at 73 Fed. Reg. 22,162 (Apr. 24, 2008).

${ }^{26} 36$ C.F.R. $\S 220$ (2018).
} 
agencies, and is largely exempt from the requirements for its Clean Air Act ("CAA") activities. ${ }^{27}$ The NEPA regulations of these agencies are discussed below. ${ }^{28}$

After the CEQ regulations were promulgated in 1978, the U.S. Supreme Court began to restrict the broad interpretations of NEPA developed by the lower federal courts, particularly the U.S. Court of Appeals for the D.C. Circuit. In Vermont Yankee Nuclear Power Corp. v. Natural Resources Defense Council, Inc., the Supreme Court held that NEPA's requirements are "essentially procedural," ending efforts by environmentalists to establish substantive rights under NEPA. ${ }^{29}$ In Strycker's Bay Neighborhood Council, Inc. v. Karlen, the Court reiterated that once an agency meets its procedural requirements under NEPA, "the only role for a court is to insure that the agency has considered the environmental consequences" of its actions. ${ }^{30}$ Today the primary responsibility of the courts in NEPA cases is to determine whether the federal agency has taken a hard look at the project covered by the EA or EIS to ensure the agency has adequately considered and disclosed the environmental impact of the proposed action. ${ }^{31}$

The first step in a NEPA analysis is to determine whether there is a major federal action significantly affecting the quality of the human environment..$^{32}$ The term "major" reinforces the term "significantly," but does not have an independent meaning. ${ }^{33}$ NEPA is triggered easily. ${ }^{34}$ If there is a substantial question concerning whether an action will have a significant effect, NEPA is triggered.$^{35}$ However, insignificant actions such as a one mile per gallon change in the Corporate Average Fuel Economy standards does not trigger NEPA. ${ }^{36}$

${ }^{27}$ Barry S. Neuman, Implementation of the Clean Air Act: Should NEPA Apply to the Environmental Protection Agency, 3 ECOLOGY L. Q. 597, 597-98 (1973).

${ }^{28}$ See Energy Supply and Environmental Coordination Act of 1974, § 7, 15 U.S.C. $\S 793(\mathrm{c})(1)(2017)$.

${ }^{29}$ Vt. Yankee Nuclear Power Corps. v. Nat. Res. Def. Council, 435 U.S. 519, 558 (1978).

${ }^{30}$ Strycker's Bay Neighborhood Council v. Karlen, 444 U.S. 223, 226 (1980).

${ }^{31}$ Balt. Gas \& Elect. Co. v. Nat. Res. Def. Council, 462 U.S. 87, 98 (1983).

${ }^{32}$ NEPA $§ 102,83$ Stat. 852, 853 (1970) (codified as amended at 42 U.S.C. $\S \S 4331-70$ (2017)).

${ }^{33} 40$ C.F.R. $\S 1508.18$ (2018).

${ }^{34}$ See, e.g., Anglers of the Au Sable v. U.S. Forest Serv., 565 F. Supp. 2d 812, 815-16 (E.D. Mich. 2008).

${ }^{35}$ See, e.g., Blue Mountain Biodiversity Project v. Blackwood, 161 F.3d 1208, 1212 (9th Cir. 1998).

${ }^{36}$ Los Angeles v. Nat’l Highway Safety Admin., 912 F.2d 478, 481-82 (D.C. Cir. 1990). 
CEQ regulations allow agencies to identify actions that (1) normally require an EIS; (2) those that normally do not require an EIS, which are known as categorical exclusions; and (3) those that normally require an EA but do not necessarily require an EIS. ${ }^{37}$ A categorical exclusion may not apply under extraordinary circumstances, such as when the Endangered Species Act is applicable to the subject of an agency's review. ${ }^{38}$ Each agency provides a list of its categorical exclusions. ${ }^{39}$

NEPA applies to broad federal actions such as new programs or regulations, which can lead to the need for a Programmatic EIS ("PEIS"). ${ }^{40}$ Tiering is used to proceed from policy development to site-specific planning without dealing with issues that were previously adequately covered. ${ }^{41}$ If new information becomes available after an EIS is completed, a supplemental EIS may be needed. ${ }^{42}$

\section{A. Reasonable Alternatives}

One of the most litigated issues involves the CEQ's regulatory requirement to consider reasonable alternatives. ${ }^{43}$ Appropriate alternatives are to be considered for "any proposal which involves unresolved conflicts concerning alternative uses of available resources." ${ }^{44} \mathrm{~A}$ federal agency may not take any action that would prejudice the selection of an alternative action prior to its making a decision on a project. ${ }^{45}$ The regulations impose six requirements relating to the alternatives analysis. ${ }^{46}$ They are (1) all reasonable alternatives must be considered and an explanation is required for any alternative excluded from future study; (2) each alternative must be considered in a manner that allows reviewers to evaluate the merits of an option; (3) alternatives outside the jurisdiction of the agency must be considered; (4) a "no action" alternative must be considered; (5) a preferred alternative must be identified;

\footnotetext{
${ }^{37} 40$ C.F.R. $\S 1507.3$ (b) (2018). Categorical exclusions are defined at 40 C.F.R. $§ 1508.4$ (2018).

${ }^{38}$ California v. Norton, 311 F.3d 1162, 1175 (9th Cir. 2002).

${ }^{39}$ See, e.g., Dep't of Energy, 10 C.F.R. § 1021, apps. A-B (2018).

${ }^{40} 40$ C.F.R. $\$ 1502.4(\mathrm{~b})$ (2018). See also CEQ, EXEC. OFFICE OF THE PRESIDENT, EFFECTIVE USE OF PROGRAMMATIC NEPA REVIEWs (2014).

${ }^{41} 40$ C.F.R. $\S 1508.28$ (2018).

${ }^{42} I d . \S 1508.25$.

${ }^{43}$ Id. $\S \S 1500.2(\mathrm{~b}), 1500.2(\mathrm{e}), 1502.13$.

${ }^{44}$ Id. $\S 1501.2(\mathrm{c})$.

${ }^{45} I d . \S \S 1502.2(\mathrm{f}), 1506.1(\mathrm{a})$.

${ }^{46} I d . \S 1502.14$.
} 
and (6) mitigation measures for the proposed action and for alternatives must be considered. ${ }^{47}$ Direct, indirect, and cumulative impacts are to be considered. ${ }^{48}$ However, alternatives that are not reasonably available need not be considered. ${ }^{49}$ Moreover, alternatives that are not brought to an agency's attention need not be evaluated. ${ }^{50}$ Cumulative impacts occur if an action, when added to other past, present, and reasonably foreseeable future actions, can collectively have a significant impact on the environment. ${ }^{51}$ This type of impact is particularly relevant to issues of climate change. However, whether climate change must be considered when evaluating alternatives is controversial, and is discussed below.

\section{B. Mitigation}

The CEQ regulations require agencies to discuss potential mitigation measures. ${ }^{52}$ Guidance concerning NEPA's requirements for mitigation and monitoring of GHG emissions was issued on January $21,2011 .{ }^{53}$ This guidance calls for mitigation measures to be explicitly described and for measurable performance standards to be included. ${ }^{54}$ The appendix to the guidance provides an overview of a regulation adopted by the Department of the Army, which the CEQ uses as a model for mitigation and monitoring efforts. ${ }^{55}$ Mitigation efforts can reduce the potentially significant environmental effects of proposed actions that would otherwise require an EIS, which could allow the agency to issue a FONSI, or a "mitigated FONSI" if mitigation is used to support the FONSI. ${ }^{56}$ Monitoring is required for

\footnotetext{
${ }^{47} \mathrm{Id}$.

${ }^{48} 40$ C.F.R. $\S 1508.25$ (c) (2018). In doing a cumulative impact analysis, an agency must assess the impact the proposed project will have in conjunction with other projects in the same and surrounding areas and must include past, present, and reasonably foreseeable future actions of any agency or person. WildEarth Guardians v. Bureau of Land Mgmt., 8 F. Supp. 3d 17, 31 (D.D.C. 2014).

${ }^{49}$ See Nat. Res. Def. Council, Inc. v. Morton, 458 F.2d 827, 834-35 (D.C. Cir. 1972) (concluding that oil and gas lease sale off Louisiana's coast need not consider oil shale, tar sands, geothermal energy, or other undeveloped alternative energy sources). See also Colo. Envtl. Coal. v. Dombeck, 185 F.3d 1162, 1174-75 (10th Cir. 1999).

${ }^{50} \mathrm{Vt}$. Yankee, 435 U.S. at 519, 553-54.

${ }^{51} 40$ C.F.R. $\S 1508.7$ (2018).

${ }^{52}$ Id. $\S \S 1502.14(\mathrm{f}), 1502.16(\mathrm{~h}), 1505.2(\mathrm{c}), 1508.25(\mathrm{~b})(3)$ (2018).

${ }^{53}$ Final Guidance for Federal Departments and Agencies on the Appropriate Use of Mitigation and Monitoring and Clarifying the Appropriate Use of Mitigated Findings of No Significant Impact, 76 Fed. Reg. 3843, 3844 (Jan. 21, 2011) [hereinafter Final Guidance].

${ }^{54} I d$. at 3848.

${ }^{55} \mathrm{Id}$. at $3851-52$.

${ }^{56} I d$. at 3848.
} 
mitigation commitments, and the agency is responsible for public dissemination of the information. ${ }^{57}$

Mitigation includes: (1) avoiding an impact by not taking a certain action or parts of an action; (2) minimizing an impact by limiting the degree or magnitude of the action and its implementation; (3) rectifying an impact by repairing, rehabilitating, or restoring the affected environment; (4) reducing or eliminating an impact over time, through preservation and maintenance operations during the life of the action; and (5) compensating for an impact by replacing or providing substitute resources or environments. ${ }^{58}$

The extent to which actions must be taken to mitigate climate change is unresolved.

\section{The CEQ's GuidAnce CONCERNING THE APPLICATION OF NEPA to Climate Change}

The CEQ issued "Draft NEPA Guidance on Considerations of the Effects of Climate Change and Greenhouse Gas Emissions" on February $18,2010 .^{59}$ It affirmed the applicability of NEPA to GHG emissions and climate change, and urged federal agencies to mitigate adverse impacts of GHG emission through reduction efforts and adaptation measures. ${ }^{60}$ Agencies were instructed to perform a NEPA analysis for a proposed action having an impact on GHG emissions and climate change, and were to consider alternative actions which could include carbon capture and sequestration. ${ }^{61}$ The draft guidance recommended that agencies prepare assessments when direct annual releases of carbon dioxide equivalent $\left(\mathrm{CO}_{2 \mathrm{e}}\right)$ emissions are 25,000 metric tons per year ("tpy") or more. ${ }^{62}$ For emissions below the 25,000 tpy trigger, the CEQ advised, but did not require, agencies to conduct similar assessments. ${ }^{63}$

\footnotetext{
${ }^{57} I d$. at 3850.

${ }^{58} \mathrm{Id}$. at 3847. See also the definition of mitigation at 40 C.F.R. $\S 1508.20$ (2018).

${ }^{59} \mathrm{CEQ}$, DRAFT NEPA GuIdANCE ON CONSIDERATION OF THE EFFECTS OF Climate Change AND GREENHOUSE GAS EMISSIONS (2010).

${ }^{60} I d$. at 1 .

${ }^{61} I d$. at 1,6 .

${ }^{62} I d$. at 1,3 .

${ }^{63}$ Id. at 1-2. See Neil McAliley, NEPA and Assessment of Greenhouse Gas Emissions, 41 ELR NEWS \& ANALYSIS 10197, 10202 (2011).
} 
On December 24, 2014, the CEQ promulgated a "Revised Draft Guidance for Federal Departments and Agencies on Consideration of Greenhouse Gas Emissions and the Effects of Climate Change in NEPA Reviews." ${ }^{44}$ It superseded the February 18, 2010 guidance, and it made it clear that GHG evaluations are required for land and resource management activities. ${ }^{65}$

This revised draft guidance: (1) Discusses direct, indirect, and cumulative impacts analysis of a proposed action's reasonably foreseeable emissions and effects; (2) highlights the consideration of reasonable alternatives and points to the need to consider the short-term and long-term effects and benefits in the alternatives analysis and mitigation to lower emissions; (3) recommends that agencies use a reference point to determine when GHG emissions warrant a quantitative analysis taking into account available GHG quantification tools and data that are appropriate for proposed agency actions; (4) recommends that an agency select the appropriate level of action for NEPA review at which to assess the effects of GHG emissions and climate change, either at a broad programmatic or landscape-scale level or at a project- or site-specific level, and that the agency set forth a reasoned explanation for its approach; (5) counsels agencies to use the information developed during the NEPA review to consider alternatives that are more resilient to the effects of a changing climate; and (6) advises agencies to use existing information and tools when assessing future proposed action, and provides examples of some existing sources of scientific information. ${ }^{66}$

On August 1, 2016, the CEQ issued "Final Guidance for Federal Departments and Agencies on Consideration of Greenhouse Gas Emissions and the Effects of Climate Change in Environmental Policy Act Reviews." 67

\footnotetext{
${ }^{64}$ Revised Draft Guidance for Federal Departments and Agencies on Consideration of Greenhouse Gas Emissions and the Effects of Climate Change in NEPA Reviews. 79 Fed. Reg. 77,802 (Dec. 24, 2014) (superseding "Draft NEPA Guidance on Consideration of the Effects of Climate Change and Greenhouse Gas Emissions").

${ }^{65} I d$. at 77,802 .

${ }^{66}$ Id. See also Sierra Club v. Fed. Energy Reg. Comm'n, 827 F.3d 59 (D.C. Cir. 2016).

${ }^{67}$ CEQ, Exec. OfFice of the President, Final Guidance for FEDERAL DePartments
} 
The guidance was intended to ensure that the analysis of potential GHG emissions is commensurate with the extent of the effects of the proposed action. ${ }^{68} \mathrm{CEQ}$ did not expect agencies to develop new NEPA implementation procedures, but it recommended agencies update their procedures if necessary ${ }^{69}$ Agencies were to consider the effects of a proposed action on climate change and the effects of climate change on the proposed action. ${ }^{70}$ Direct and indirect GHG emissions were to be quantified where feasible. ${ }^{71}$ The guidance provided substantial detail as to what is required, but that is now irrelevant because on April 5, 2017, the Trump administration withdrew the CEQ's 2016 GHG guidance document. ${ }^{72}$ The guidance was withdrawn for further consideration, and the withdrawal "does not change any law, regulation, or other legally binding requirement." ${ }^{73}$

On June 20, 2018, CEQ issued an Advance Notice of Proposed Rulemaking that stated it was considering updating its implementing regulations for the procedural provisions of NEPA. ${ }^{74}$ It requested comments on the following, lightly edited, twenty questions:

1. Should CEQ's NEPA regulations be revised to ensure that environmental reviews and authorization decisions involving multiple agencies are conducted in a manner that is concurrent, synchronized, timely, and efficient, and if so, how?

2. Should CEQ's NEPA regulations be revised to make the NEPA process more efficient by better

\footnotetext{
AND AGEnCies on Consideration of GreEnhouse Gas EMissions And the EFFECTS of Climate Change in National Environmental Policy ACt Reviews (2016).

${ }^{68} I d$. at 1.

${ }^{69} \mathrm{Id}$. at 3.

${ }^{70} I d$. at 4.

${ }^{71} I d$.

${ }^{72}$ Withdrawal of Final Guidance for Federal Departments and Agencies on Consideration of Greenhouse Gas Emissions and the Effects of Climate Change in National Environmental Policy Act Reviews, 82 Fed. Reg. 16,576, 16,576 (Apr. 5, 2017). See also Dawn Reeves, Trump Faces Murky Process to Revoke NEPA Climate Guide, Source Says, InsIDE EPA(Mar. 23, 2017), https://insideepa.com/daily-news/trump-faces-murky-process-revoke -nepa-climate-guide-source-says [https://perma.cc/TQ73-L8BM].

${ }^{73}$ Withdrawal of Final Guidance for Federal Departments and Agencies on Consideration of Greenhouse Gas Emissions and the Effects of Climate Change in National Environmental Policy Act Reviews, 82 Fed. Reg. 16,576, 16,576-77.

${ }^{74}$ Update to the Regulations for Implementing the Procedural Provisions of the National Environmental Policy Act, 83 Fed. Reg. 28,591, 28,591 (June 20, 2018).
} 
facilitating agency use of environmental studies, analysis, and decisions conducted in earlier Federal, State, tribal or local environmental reviews or authorization decisions, and if so, how?

3. Should CEQ's NEPA regulations be revised to ensure optimal interagency coordination of environmental reviews and authorization decisions, and if so, how?

\section{Scope of Review}

4. Should the provisions in CEQ's ... regulations that relate to the format and page length of the NEPA documents and time limits for completion be revised, and if so, how?

5. Should CEQ's ... regulations be revised to provide greater clarity to ensure ... documents better focus on significant issues that are relevant and useful to decisionmakers and the public, and if so, how?

6. Should the provisions in CEQ's . . . regulations relating to public involvement be revised to be more inclusive and efficient, and if so, how?

7. Should definitions of any key terms in the NEPA regulations, such as Major Federal Action; Effects; Cumulative Impact; Significantly; Scope; and other terms found in the statute be revised, and if so, how?

8. Should any new definitions of terms such as Alternatives; Purpose and Need; Reasonably Foreseeable; Trivial Violation; and other NEPA terms be added, and if so, which terms?

9. Should the provisions in the NEPA regulations relating to the documents Notice of Intent; Categorical Exclusions Documentation; Environmental Assessments; Findings of No Significant Impact; 
Environmental Impact Statements; Records of Decision; and Supplements be revised, and if so, how?

10. Should the provisions in ... NEPA regulations relating to the timing of agency action be revised, and if so, how?

11. Should the provisions in ... NEPA regulations relating to agency responsibility and the preparation of documents by contractors and project applicants be revised, and if so, how?

12. Should the provisions in ... NEPA regulations relating to programmatic ... documents and tiering be revised, and if so, how?

13. Should the provisions in ... NEPA regulations relating to the appropriate range of alternatives ... be eliminated from detailed analysis be revised, and if so, how?

\section{General}

14. Are any specific provisions of the NEPA regulations obsolete? If so, they should be modified, rescinded, or replaced.

15. Which provisions of the NEPA regulations can be updated to reflect new technologies to make the process more efficient?

16. Are there additional ways NEPA regulations should be revised to promote coordination of environmental review and authorization decisions, such as combining other decision documents with the NEPA analysis, and if so, how?

17. Are there additional ways NEPA regulations should be revised to improve the efficiency and effectiveness of NEPA's implementation, and if so, how? 
18. Are there ways in which NEPA's regulations could be clarified concerning the role of tribal governments, and if so, how?

19. Are there additional ways NEPA's regulations should be revised to ensure that agencies apply the statute in a manner that reduces unnecessary burdens and delays as much as possible, and if so, how?

20. Are there additional ways NEPA regulations related to mitigation should be revised, and if so, how? ${ }^{75}$

III. The White House Proposal to Streamline InfRastructure PERMITTING

On February 12, 2018, the Trump administration released a set of proposals to streamline the federal environmental review process for infrastructure projects. ${ }^{76}$ The proposal included a Part 3-Permitting Principles. ${ }^{77}$ Among its provisions are amendments to NEPA and other environmental statutes as well as changes in the roles of federal environmental agencies and the federal courts. ${ }^{78}$ The changes would include:

Creating a new "One Agency, One Decision" structure for environmental reviews to encourage collaboration and effective communication by establishing deadlines and requiring the Permitting Council to either grant agencies an extension to the deadlines or reassigning the decisions for the permit to the lead Federal agency.

Eliminating redundancies by removing multiple reviews by multiple agencies.

\footnotetext{
${ }^{75} I d$. at $28,591-92$.

${ }^{76}$ Building a Stronger America: President Donald J. Trump's American Infrastructure Initiative, WHITE HOUSE (Feb. 12, 2018), https://www.whitehouse.gov/briefings-statements /building-stronger-america-president-donald-j-trumps-american-infrastructure-initiative/ [https://perma.cc/88RH-WURU].

${ }^{77}$ Legislative Outline for Rebuilding Infrastructure in America, DEPARTMENT OF TRANSPORTATION 1, 35 (2018), https://www.transportation.gov/sites/dot.gov/files/docs/briefing -room/304441/legoutline.pdf [https://perma.cc/KC4R-H8YD] (last visited Nov. 17, 2018). ${ }^{78} I d$.
} 
Delegating more responsibilities to States.

Providing for additional provisions to facilitate environmental reviews across the applicable Federal Agencies. ....

Authorizing pilot programs through which agencies may experiment with innovative approaches to environmental reviews while enhancing environmental protections.

Reexamining certain judicial review standards to ensure that issues are quickly resolved. ${ }^{79}$

The proposal would change NEPA to require a FONSI or a ROD, as appropriate, to be issued within twenty-one months. ${ }^{80}$ Federal agencies and states with federal delegation would then have three months to make permit decisions. ${ }^{81}$ If a federal agency fails to meet the deadlines, its responsibilities, along with an appropriate amount of budgetary authority, could be transferred to a new lead agency. ${ }^{82}$ The lead agency would have significantly more authority to limit the influence of other agencies, including the power to determine the range of alternatives considered ${ }^{83}$ The requirement for reasonable alternatives to be considered would be restricted to alternatives that can legally, technically, and economically be implemented. ${ }^{84}$ The CEQ would be required to issue regulations and guidance to streamline the NEPA process and the EPA would lose its review responsibility under the Clean Air Act's Section $309 .^{85}$ The proposal also provides for expanded use of categorical exclusions ${ }^{86}$ In addition to changes in NEPA, the proposal would change the Clean Air Act, the Clean Water Act, the Endangered Species Act, and other federal statutes to limit environmental considerations when authorizing infrastructure projects. ${ }^{87}$

\footnotetext{
${ }^{79}$ Legislative Outline for Rebuilding Infrastructure in America Draft, pt. 3 (2018), https:// www.cdfa.net/cdfa/cdfaweb.nsf/0/70544C496B334DB9882582250053DE39/\$file/White -House-Draft-Plan-to-Streamline-Federal.pdf [https://perma.cc/DR9U-UJPR].

${ }^{80} I d . \S 3000$.

${ }^{81} I d$.

${ }^{82}$ Id. See also Trump Permitting Plan Would Scale Back NEPA, Limiting EPA's Reviews, INSIDE EPA(Feb. 9, 2018), https://insideepa.com/daily-news/trump-permitting-plan-would -scale-back-nepa-limiting-epas-reviews [https://perma.cc/886Q-3MAU].

${ }^{83}$ Legislative Outline for Rebuilding Infrastructure in America Draft, supra note 79, at $\S \S 3001,3002,3003$.

${ }_{84}^{8} I d . \S 3005$.

${ }^{85} I d . \S \S 3006-07$.

${ }^{86} I d . \S \S 3009,3405$.

${ }^{87}$ Id. $\S \S 3013-3302$.
} 
The Trump administration also seeks to narrow the scope of judicial review by exempting certain actions or issues from review by the courts. ${ }^{88}$ Categorical exclusions created by federal agencies would not be subject to judicial review. ${ }^{89}$ Moreover, courts could stop a project only under exceptional circumstances, ${ }^{90}$ and the statute of limitations for challenges would be cut from up to five years to 150 days. ${ }^{91}$

\section{Executive ORDers Related to Climate Change}

NEPA's requirements have been expanded by Executive Orders ("E.O.s"), which include requirements directed at climate change. Former President Bush's E.O. 13,423 directs each federal agency to reduce their energy intensity and increase their use of renewable energy. ${ }^{92}$ President Obama's E.O. 13,514, issued on October 5, 2009, expanded the requirements of E.O. 13,423. ${ }^{93}$ Guidance for implementing E.O. 13,514 was promulgated on March 4, 2011. ${ }^{94}$ It required that each agency address the challenges posed by climate change to its mission, programs, and operations: "Federal agencies shall increase energy efficiency; measure, report, and reduce their greenhouse gas emissions from direct and indirect activities." Performance Plan" that includes GHG reduction targets for GHG emissions from the sources controlled by a federal agency and from sources generating electricity purchased by a federal agency. ${ }^{96}$ Section 16 of the E.O. requires the Interagency Climate Change Adaptation Task Force to develop recommendations for federal agencies to guide them in developing climate adaptation plans. ${ }^{97}$ The Task Force's recommendations were adopted by

\footnotetext{
${ }^{88} I d . \S \S 3401-06$.

${ }^{89}$ Legislative Outline for Rebuilding Infrastructure in America Draft, supra note 79, at $\S 3405$.

${ }_{90} I d . \S 3402$.

${ }^{91} I d . \S \S 3403-04$.

${ }^{92}$ Strengthening Federal Environmental, Energy, and Transportation Management, Exec. Order No. 13,423, 72 Fed. Reg. 3,919 (Jan. 26, 2007).

${ }^{93}$ Federal Leadership in Environmental, Energy, and Economic Performance, Exec. Order No. 13,514, 74 Fed. Reg. 52,117 (Oct. 8, 2009).

${ }^{94} \mathrm{CEQ}$, Federal Agency Climate Change Adaptation Planning: Implementation Instructions (Mar. 4, 2011), https://www.nrc.gov/docs/ML1108/ML110811218.pdf [https://perma.cc/TR Q8-7HS3].

${ }^{95}$ Federal Leadership in Environmental, Energy, and Economic Performance, 74 Fed. Reg. at 52,117 (Oct. 5, 2009).

${ }^{96}$ Id. at 52,117 and 52,126 .

${ }^{97}$ Interagency Climate Change Adaptation Task Force, Progress Report of the Interagency Climate Change Adaptation Task Force: Recommended Actions in Support of a
} 
the CEQ. ${ }^{98}$ By June 4, 2012, each agency was to submit to the CEQ and to the Office of Management and Budget ("OMB") its climate adaptation plan, which was to be made publicly available, for fiscal year $2013 .{ }^{99} \mathrm{In}$ 2010 , the federal government announced it would reduce its GHG emissions 28 percent by 2020 based on the aggregate of 35 federal agencies' self-reported targets. ${ }^{100}$

After Donald Trump became president in 2017, a seismic change in the nation's environmental policy occurred. Public health concerns are now secondary to expanding the production of fossil fuels. Minimizing the costs imposed on the regulated community is now a paramount concern when regulatory programs are developed and implemented. ${ }^{101}$ After taking office, President Trump almost immediately issued E.O. 13,771, which requires agencies to eliminate two regulations when a new regulation is promulgated and to fully offset the cost of any new regulation. ${ }^{102}$ This E.O. has been subject to significant criticism from economists. ${ }^{103} \mathrm{On}$ March 1, 2017, a regulatory process was established by E.O. 13,777 to comply with E.O. 13,771. ${ }^{104}$ Each agency is to follow this process when recommending rules to be eliminated. ${ }^{105}$ On April 5, 2017, the Office of Information and Regulatory Affairs issued guidance to the agencies to implement the two-for-one regulatory mandate. ${ }^{106}$ The E.O. makes it more

National Climate Change Adaptation Strategy 2 (2010), https://web.archive.org/web/2016 1201153437/https://www.whitehouse.gov/sites/default/files/microsites/ceq/Interagency -Climate-Change-Adaptation-Progress-Report.pdf [https://perma.cc/3TXT-HY5F].

${ }^{98}$ CEQ, supra note 94.

${ }^{99} \mathrm{Id}$.

${ }^{100}$ Press Release, Office of the Press Secretary, President Obama Sets Greenhouse Gas Emissions Reduction Target for Federal Operations (Jan. 29, 2010), http://www.white house.gov/the-press-office/president-obama-sets-greenhouse-gas-emissions-reduction-tar get-federal-operations [https://perma.cc/HQ94-J4U4].

${ }^{101}$ See Cheryl Hogue, Trump administration is considering reweighing costs and benefits of EPA regulations, CHEM. \& ENG'G NEWS (Aug. 5, 2018), https://cen.acs.org/policy /regulation/Trump-administration-considering-reweighing-costs/96/i32 [https://perma.cc 147AE-XZWR].

${ }^{102}$ Reducing Regulation and Controlling Regulatory Costs, Exec. Order No. 13,771, 82 Fed. Reg. 9339 (Feb. 3, 2017).

${ }^{103}$ Dave Reynolds, Agency Economists Say 2-1 Order 'Doubles'Benefit-Cost Analysis Work, INSIDE EPA (Oct. 2, 2017).

${ }^{104}$ Enforcing the Regulatory Reform Agenda, Exec. Order No. 13,777, 82 Fed. Reg. 12,285 (Mar. 1, 2017).

${ }^{105} I d$

${ }^{106}$ Doug Obey, OMB Guide Highlights Burdens EPA Faces Issuing Rules Under 2-1 Order, INSIDE EPA(May 1, 2017), https://insideepa.com/daily-news/omb-guide-highlights -burdens-epa-faces-issuing-rules-under-2-1-order [https://perma.cc/VV6G-MDLM]. 
difficult to develop regulations and increases the work load for EPA at a time when its budget and personnel are being cut.

On March 27, 2017, President Trump signed legislation repealing the Department of the Interior's Bureau of Land Management ("BLM")'s Planning 2.0 regulation. ${ }^{107}$ The Planning 2.0 Rule was promulgated at the end of the Obama administration. ${ }^{108}$ Led by conservative western members of Congress, the House passed a resolution of disapproval of the 2.0 regulation on February 7, 2017, based on the authority granted by the Congressional Review Act ("CRA"). ${ }^{109}$ On March 7, 2017, the Senate passed a resolution of disapproval. ${ }^{110}$ After the President signed the legislation, the CRA statute lead to the Planning 2.0 Rule being treated as if it had never taken effect. Thus, the planning requirements returned to the pre-January 11, 2017, regulations, which are the 1983 regulations that are far less protective of the environment. ${ }^{111}$ Subsequently, the Department of Interior published a rule removing the voided text of the rule and nullified any actions made by the rule. ${ }^{112}$ The demise of the Planning 2.0 Rule is considered by environmentalists to be a serious blow to improved management of public lands, which includes the need for better protection of the environment from the energy industry's operations. ${ }^{113}$ While NEPA's procedural requirements still apply to BLM's planning activities, the more rigorous substantive requirements of the 2.0 Rule have been revoked.

President Trump issued E.O. 13,783, "Promoting Energy Independence and Economic Growth," on March 28, 2017. ${ }^{114}$ This Order directs all executive branch agencies to review existing regulations for burdensome effects on the "[s]afe, [e]fficient [d] evelopment of [d] omestic [e]nergy

\footnotetext{
${ }^{107}$ Pub. L. No. 115-12, 131 Stat. 76 (2017).

${ }^{108}$ Resource Management Planning Rule, 81 Fed. Reg. 89,580 (Dec. 12, 2016).

${ }^{109}$ H.R.J. Res. 44, 115th Cong. (2017). The CRA can be found at 5 U.S.C. $\$ 801$ (2018). See also RIPON ADVANCE News SERV., Trump signs repeal of BLM Planning 2.0 regulation under Congressional Review Act, THE RIPON ADVANCE (Mar. 29, 2017), https://riponad vance.com/stories/trump-signs-repeal-blm-planning-2-0-regulation-congressional-review -act/ [https://perma.cc/98WC-2MLP].

${ }^{110}$ H.J. Res. 15 (Mar. 7, 2017) CoNG. REC. S1686-S1687.

${ }^{111}$ See, e.g., Bobby McEnaney, Congress Kills BLM's Planning 2.0 Rule, NAT. REs. Def. COUNCIL BLOG (Mar. 7, 2017), https://www.nrdc.org/experts/bobby-mcenaney/congress kills-blms-planning-20-rule [https://perma.cc/S8ZT-XDVG]

${ }^{112}$ Effectuating Congressional Nullification of the Resource Management Planning Rule Under the Congressional Review Act, 82 Fed. Reg. 60,554, 60,554 (Dec. 21, 2017) (to be codified at 43 C.F.R. pt. 1600).

${ }^{113}$ McEnaney, supra note 111.

${ }^{114}$ Exec. Order No. 13,783, 82 Fed. Reg. 16,093 (Mar. 28, 2017).
} 
[s]ources." ${ }^{115}$ More specifically, the Order rescinds Obama-era energy- and climate-related regulatory actions, including E.O. 13,653, "Preparing the United States for the Impacts of Climate Change," and three Presidential Memoranda: "Power Sector Carbon Pollution Standards," "Mitigating Impacts on Natural Resources From Development and Encouraging Related Private Investment," and "Climate Change and National Security." 116 The Order also rescinds the 2013 Climate Action Plan and the 2014 Climate Action Plan Strategy to Reduce Methane Emissions. ${ }^{117}$ Additionally, the Order disbands the Interagency Working Group on the Social Cost of Carbon, Nitrous Oxide, and Methane for Regulatory Impact Analysis ("IWG"). ${ }^{118}$ Established in 2010, the IWG was responsible for a yearly social cost-benefit analysis of GHG emissions based on the most recent climate change science findings. ${ }^{119}$ The new Order directs that any further cost-benefit reports done by any executive branch agency be based on guidance contained in the OMB A-4 Circular of September 17, 2003. ${ }^{120}$

E.O. 13,783 grants significant autonomy to both EPA's Administrator and the Secretary of the Interior. For example, former Administrator Pruitt was directed to "suspend, revise, or rescind the guidance," of Obama-era EPA regulations pertaining to GHG emissions from all stationary energy sources and all oil and natural gas development sources, wherever such action is lawful and consistent with the main theme of unburdening domestic energy production. ${ }^{121}$ Section 6 of the E.O. directs the Secretary of Interior to "lift any and all moratoria on Federal land coal leasing activities," as well as suspension, revision, or rescission of federal regulations restricting oil, gas, and hydraulic fracturing on federal and Indian lands. ${ }^{122}$ This attempt to revitalize the nation's coal industry is the most specifically criticized element of the E.O. However, despite the Trump administration's support of the fossil fuel industry, it is unlikely that coal will be able to effectively compete with the less expensive and cleaner natural gas alternative. ${ }^{123}$

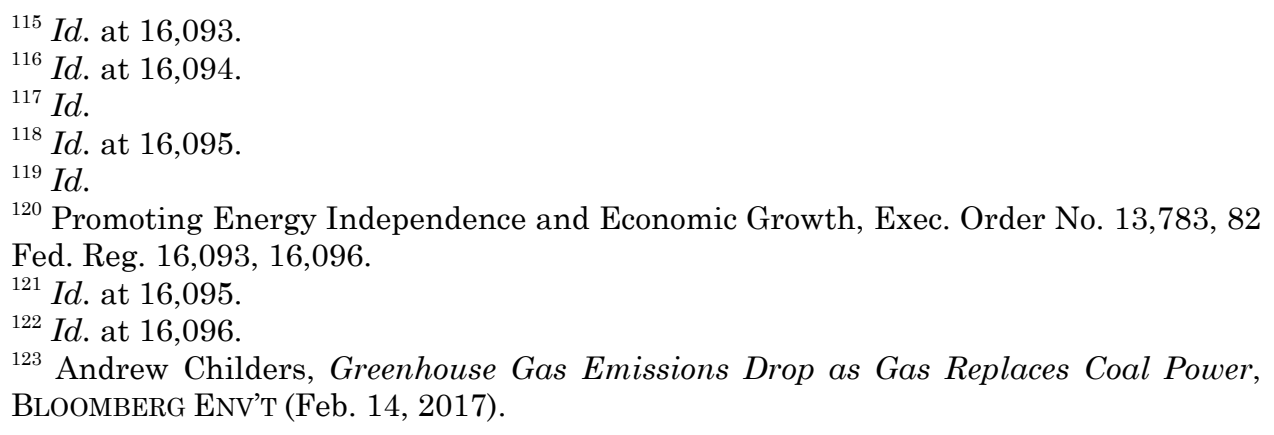


Agencies are not to spend more than a year analyzing the environmental impacts of major actions, and the final report may not exceed 150 pages or 300 pages for unusually complex projects. ${ }^{124}$ This will affect BLM's regulations promulgated on December 12, 2016, on the preparation of land use plans to include both the effect of the proposed action on climate change and the effect of climate change on the proposed action. ${ }^{125}$ As previously mentioned, the Trump administration seeks to use its infrastructure plan to reduce environmental reviews under many environmental laws and substantially limit the public's ability to use the federal courts to challenge project approvals. ${ }^{126}$

As required by Executive Order 13,783, EPA released its "Energy Independence Report" on October 25, 2017. ${ }^{127}$ It calls for reducing the regulatory burden on energy resource companies through (1) New Source Review reform; (2) National Ambient Air Quality Standards ("NAAQS") reform; (3) robust evaluations of employment effects of EPA regulations; and (4) a "Smart Sector" program through which EPA is seeking input from trade associations on co-operative problem-solving. ${ }^{128}$

On May 17, 2018, President Trump signed Executive Order 13,834, titled Efficient Federal Operations. ${ }^{129}$ It revoked Executive Order 13,693 of March 19, 2015, Planning for Federal Sustainability in the Next Decade. ${ }^{130}$ In Section 2, E.O. 13,693 created percentage reduction targets for agency wide reductions in GHG emissions to reduce emissions by the end of 2025 relative to the fiscal year 2008 baseline. ${ }^{131}$ In addition to President Trump's removing the need to reduce GHG emissions, the E.O. directs the heads of the Departments of Agriculture, Energy, General Services Administration, and EPA in conjunction with the CEQ to

\footnotetext{
${ }^{124}$ Michael Doyle, Order limits most NEPA studies to a year, 150 pages, E\&E NEWS (Sept. 6, 2017), https://www.eenews.net/greenwire/stories/1060059865 [https://perma.cc /P4BR-CN8B].

${ }^{125}$ Resource Management Planning Rule, 81 Fed. Reg. 89,580.

${ }^{126}$ Alan Kovski, Infrastructure Plan Calls for Changes to Environmental Laws, BLOOMBERG ENV'T(Feb. 12, 2018), https://news.bloombergenvironment.com/environment-and-energy/in frastructure-plan-calls-for-changes-to-environmental-laws [https://perma.cc/VYQ7-M6F8]. ${ }^{127}$ EPA, EPA Releases Energy Independence Report (Oct. 25, 2017), https://www.epa.gov /newsreleases/epa-releases-energy-independence-report [https://perma.cc/48Q3-Y4Y9]. ${ }^{128}$ David LaRoss, EPA Touts Four 'Key' Policy Reform Efforts to Boost Trump's Energy Order, INSIDE EPA (Oct. 25, 2017).

${ }^{129}$ Efficient Federal Operations, Exec. Order No. 13,834, 83 Fed. Reg. 23,771 (May 17, 2018).

${ }^{130} I d$. at 23,773 .

${ }^{131}$ Planning for Federal Sustainability in the Next Decade, Exec. Order No. 13,693, 80 Fed. Reg. 15,871 (Mar. 25, 2015).
} 
review government guidance related to energy and environmental performance and develop a plan to modify, replace, or rescind such guidance. ${ }^{132}$

On August 15, 2017, E.O. 13,807 directed CEQ to develop an initial list of actions to enhance and modernize the federal environmental review and authorization process. ${ }^{133}$ In response, CEQ stated that it intends to review NEPA's existing regulations in order to identify changes needed to update and clarify these regulations. ${ }^{134}$ This resulted in the June 20, 2018, Advance Notice of Proposed Rulemaking previously discussed. ${ }^{135}$

\section{SPECIFIC AGENCY NEPA REGULATIONS}

As mentioned previously, NEPA requires all federal agencies to review their statutory authority, administrative regulations, procedures, and policies to determine whether there are any deficiencies or inconsistencies that prevent full compliance with NEPA. ${ }^{136}$ The NEPA regulations promulgated by several federal agencies with environmental responsibilities are briefly discussed below. However, the agencies have largely ignored the issue of what role GHG emissions and climate change should play when carrying out their mission responsibilities.

\section{A. The Department of Energy's NEPA Regulations}

The Department of Energy ("DOE") promulgated regulations to supplement CEQ's regulations. ${ }^{137}$ Subpart A of the regulations covers the general applicability of NEPA to DOE. ${ }^{138}$ DOE's regulations include added definitions to the CEQ regulations. ${ }^{139}$ DOE's General Counsel is responsible for overseeing NEPA compliance. ${ }^{140}$ Subpart B, which guides DOE's NEPA compliance, parallels the CEQ's regulations. The DOE regulations

\footnotetext{
${ }^{132}$ Efficient Federal Operations, Exec. Order No. 13,834, 83 Fed. Reg. 23,771, 23,771-72 (May 17, 2018).

${ }^{133}$ Establishing Discipline and Accountability in the Environmental Review and Permitting Process for Infrastructure Projects, Exec. Order No. 13,807, 82 Fed. Reg. 40,463, 40,466 (Aug. 24, 2017).

${ }^{134} \mathrm{Id}$. at 40,467 .

${ }^{135}$ Update to the Regulations for Implementing the Procedural Provisions of the National Environmental Policy Act, 83 Fed. Reg. at 28,591.

${ }^{136}$ NEPA, 42 U.S.C. $§ 4333$ (2018).

${ }^{137}$ NEPA Implementing Procedures, 10 C.F.R. $§ 1021.100$ (2018).

${ }^{138}$ Id. $\S 1021.102$ (a) (stating that NEPA applies to the entire DOE with the exception of the Federal Energy Regulatory Commission).

${ }^{139}$ Id. § 1021.104(b).

${ }^{140}$ Id. $\S 1021.105$.
} 
cover the level of review required for a project or action, ${ }^{141}$ including research and development activities, rulemaking, adjudicatory proceedings, applications for permits and licenses, and government procurement and financial assistance. ${ }^{142}$

Subpart C regulates the procedures implementing NEPA. ${ }^{143}$ It covers the preparation of EAs and EISs and the applicability of exclusions. ${ }^{144}$ It covers the use of an EA, a FONSI, a programmatic EA or EIS, and of mitigation action plans. ${ }^{145}$ Subpart $\mathrm{C}$ also covers public review of an EIS. ${ }^{146}$ DOE must publish a ROD in the Federal Register before action is taken on a proposal. ${ }^{147}$

Subpart D discusses the level of review for typical actions taken by DOE. ${ }^{148}$ Appendix A of this section identifies categorical exclusions applicable to general agency actions. ${ }^{149}$ Appendix B identifies the categorical exclusions applicable to specific agency actions. ${ }^{150}$ Categorical exclusions must not violate applicable laws or adversely affect environmentally sensitive resources. ${ }^{151}$ Appendix $\mathrm{C}$ covers classes of actions that normally require an EA but not necessarily an EIS, and Appendix D deals with classes of actions that usually require an EIS. ${ }^{152}$

DOE's regulations adopt CEQ's regulations concerning implementing NEPA. ${ }^{153}$ However, DOE's regulations provide no guidance concerning the treatment of climate change issues.

\section{B. The Department of the Interior and its BLM NEPA Requirements}

The U.S. Department of the Interior's ("DOI") NEPA policy is found in its departmental manual. ${ }^{154}$ Series 31 of the manual deals with environmental quality programs. ${ }^{155}$ Part 516 deals with NEPA, and it is focused

\footnotetext{
${ }^{141}$ Id. $\S 1021.200(\mathrm{c})$.

${ }^{142} I d . \S \S 1021.212-1021.216$.

${ }^{143} 10$ C.F.R. $\$ 1021.300$.

${ }^{144} I d . \S \S 1021.300-1021.311$.

${ }^{145}$ Id. $\S \S 1021.321-1021.331$.

${ }^{146}$ Id. $\$ 1021.313$.

${ }^{147} I d . \S \S 1021.315(\mathrm{~b})-(\mathrm{d})$.

${ }^{148} I d . \S 1021.400$.

14910 C.F.R. $\S 1021(D)$, app. A.

${ }^{150} 10$ C.F.R. $\S 1021(\mathrm{D})$, app. B.

${ }^{151} I d . \S 1021(\mathrm{D})$, app. B.B(4).

${ }^{152} I d . \S 1021(\mathrm{D})$, apps. C-D.

${ }^{153} 10$ C.F.R. $\S 1021.103$.

${ }^{154}$ U.S. DEP'T OF INTERIOR, supra note 25.

${ }^{155} I d$. at ser. 31.
} 
on the nuts and bolts of compliance. ${ }^{156}$ Part 516 , chapter 11 of the manual covers the BLM's oversight of the NEPA process. ${ }^{157}$ Part 523 deals with climate change adaptation, but it does not provide much useful guidance. ${ }^{158}$ It includes the Handbook, 707 DM1-Agency Specific Procedures for Implementing the Council on Environmental Quality's Principles, Requirements, and Guidelines for Water and Land Related Resources Implementation Studies. ${ }^{159}$ The DOI Departmental Manual Part 516, chapter 11, Managing the NEPA Process-Bureau of Land Management, 516 DM 11.3, provides guidance for applicants. ${ }^{160}$ This chapter provides supplementary requirements for implementing provisions of $516 \mathrm{DM}$ Chapters 1 through 6 for the DOI's BLM. ${ }^{161}$ It incorporates CEQ and DOI requirements as they apply to BLM's operations, including a list of the type of BLM actions that will normally require an EIS and a list of actions eligible for a categorical exclusion. ${ }^{162}$ What it does not do is provide any useful guidance concerning dealing with issues involving climate change.

The BLM's NEPA Handbook (H-1790-1) provides additional guidance for applicants. ${ }^{163}$ The BLM Handbook includes within its NEPA processes an evaluation of whether a project complies with any applicable land use plan ("LUP"). ${ }^{164}$ If a project does not conform to the LUP it may be modified in order to conform or the LUP may be modified to allow the proposed action. ${ }^{165}$ If neither of these approaches satisfies the LUP, the proposal must be abandoned. ${ }^{166}$

Projects funded by BLM or on lands managed by BLM require NEPA analysis. ${ }^{167}$ Projects on land not managed by BLM require NEPA compliance if BLM has sufficient control over the action, such that the

\footnotetext{
${ }^{156} I d$. at ser. 31, pt. 516.

${ }^{157}$ Id. at ser. 31, pt. 516, Chapter 11.

${ }^{158}$ Id. at ser. 31, pt. 523.

${ }^{159}$ DOI, Agency Specific Procedures for Implementing the Council on Environmental Quality's Principles, Requirements, and Guidelines for Water and Land Related Resources Implementation Studies, https://www.doi.gov/sites/doi.gov/files/elips/documents/707_dm_.pdf [https:// perma.cc/GL5S-NTHH].

${ }^{160}$ U.S. DEP’T OF INTERIOR, supra note 25, at pt. 516, ch. 11.

${ }^{161} I d$.

${ }^{162} I d$.

${ }^{163}$ BLM, National Environmental Policy Act Handbook H-1790-1 (Jan. 2008), https:// www.ntc.blm.gov/krc/uploads/366/NEPAHandbook_H-1790_508.pdf [https://perma.cc /ZKX5-CD79] [hereinafter BLM Handbook].

${ }^{164} I d$. at 6.

${ }^{165} \mathrm{Id}$.

${ }^{166} \mathrm{Id}$.

${ }^{167} \mathrm{Id}$. at 15 .
} 
effects can be evaluated. ${ }^{168}$ Projects involving mineral estates where BLM manages the surface and subsurface trigger NEPA analysis. ${ }^{169}$ If BLM manages the subsurface and another federal agency manages the surface, NEPA applies but BLM must establish a cooperative agency relationship. ${ }^{170}$

Categorical exclusions allow a federal action to comply with NEPA without obtaining an EA or an EIS. ${ }^{171}$ The Energy Policy Act of 2005 provides a rebuttable presumption that specified activities involving oil and gas exploration and development activities are categorically excluded. ${ }^{172}$ Appendix Four of the BLM Handbook lists categorical exclusions under subject headings such as: (1) oil, gas, and geothermal energy; (2) realty; (3) solid minerals; and (4) transportation. ${ }^{173}$ However, Appendix Five of the BLM Handbook lists twelve extraordinary circumstances, including actions with controversial or unknown environmental effects, that mandate preparation of an EA or an EIS. ${ }^{174}$ In addition, the BLM Handbook (H-1790-1) lists categorical exclusions adopted by the Department of the Interior. ${ }^{175}$ Chapter Six of the BLM Handbook examines the NEPA analysis process. ${ }^{176}$ Part 6.8 deals with environmental effects, but it provides no specific guidance on the treatment of climate change. ${ }^{177}$ Moreover, on June 6, 2018, BLM issued an information bulletin explaining the various ways that the agency can avoid issuing an EA or an EIS. ${ }^{178}$ However, even if NEPA is applicable and the agency produces an EA or an EIS, there is no assurance that climate change impacts will be addressed. For example, on July 12, 2018, BLM released its final EIS for the Alton Coal Tract Lease covering 3,581 acres of federal coal resources on lands near Alton, Utah. ${ }^{179}$ No mention of the effects on climate change were included. ${ }^{180}$

\footnotetext{
${ }^{168} I d$.

${ }^{169}$ BLM Handbook, supra note 163 , at 16 .

${ }^{170} \mathrm{Id}$.

${ }^{171} \mathrm{Id}$. at 17 .

${ }^{172} I d$. app. 2 at 141.

${ }^{173} I d$. app. 4 at $147-53$.

${ }^{174} I d$. app. 5 at 155 .

${ }^{175}$ BLM Handbook, supra note 163 , at 17.

${ }^{176} \mathrm{Id}$. at 33 .

${ }^{177} I d$. at $54-63$.

${ }^{178}$ BLM, NEPA Efficiencies for Oil and Gas Development, Information Bulletin 2018061 (June 6, 2018), https://www.blm.gov/policy/ib-2018-061 [https://perma.cc/D7ZK-6UVQ]. ${ }^{179}$ BLM Releases Final Environmental Impact Statement for the Alton Coal Tract, BLM (Jul. 12, 2018), https://www.blm.gov/press-release/blm-releases-final-environmental-im pact-statement-alton-coal-tract [https://perma.cc/K4QB-R5K4].

${ }^{180} I d$.
} 


\section{The EPA's NEPA Requirements}

The EPA is not required to comply with NEPA for most of its actions. The Clean Air Act ("CAA") exempts the Agency from the requirements of NEPA. ${ }^{181}$ Under the Clean Water Act ("CWA"), EPA must comply with the procedural requirements of NEPA for only a limited number of actions, which include its research and development activities, facilities construction, wastewater treatment construction grants, EPA-issued National Pollutant Discharge Elimination System ("NPDES") permits for new sources, and for certain projects funded through EPA's annual Appropriations Acts. ${ }^{182}$ The Comprehensive Environmental Response, Compensation, and Liability Act ("CERCLA" or "Superfund") also exempts EPA from the procedural requirements of environmental laws for its response actions. ${ }^{183}$ Court decisions have held EPA's procedures to be functionally equivalent to the NEPA process and therefore exempt from NEPA's procedural requirements. ${ }^{184}$ EPA has been voluntarily preparing EAs for many years on a case-by-case basis, and it sometimes prepares an EIS when the Agency believes it could be beneficial. ${ }^{185}$ EPA's policy document lists the criteria for making such a determination. ${ }^{186}$

EPA has played an oversight role by reviewing NEPA activities of other Federal agencies. Section 309 of the Clean Air Act gives EPA the responsibility for reviewing and commenting on the environmental impact of legislation, federal construction projects, major federal actions, and proposed regulations published by any federal agency. ${ }^{187}$ This allows EPA to influence federal agency actions, and if its Administrator determines any legislation, action, or regulation adversely impacts public health, welfare, or environmental quality, the matter can be referred to the CEQ. ${ }^{188}$

In 2011 the Department of Agriculture (on behalf of the Forest Service), and EPA disseminated a memorandum of understanding ("MOU") concerning air quality analyses and mitigation for federal oil and gas decisions through NEPA. ${ }^{189}$ The MOU establishes a common NEPA process

\footnotetext{
${ }^{181}$ See Energy Supply and Environmental Coordination Act of 1974, 15 U.S.C. § 793(c)(1).

${ }^{182}$ Notice of Policy and Procedures for Voluntary Preparation of National Environmental Policy Act (NEPA) Documents, 63 Fed. Reg. 58,045, 58,046 (Oct. 29, 1998) [hereinafter Notice of Policy and Procedures]. See also 33 U.S.C. § 1371(c)(1).

${ }^{183}$ Notice of Policy and Procedures, supra note 182, at 58,046.

${ }^{184} \mathrm{Id}$.

${ }^{185} \mathrm{Id}$.

${ }^{186} I d$. at 58,047 .

${ }^{187} 42$ U.S.C. $\S 7609$ (a).

${ }^{188}$ CAA $\S 309(b), 42$ U.S.C. $\S 7609(b)(2000)$.

${ }^{189}$ MOU Among the U.S. Dep't of Agric., U.S. Dep't of the Interior, \& U.S. Envtl. Prot. Agency, Regarding Air Quality Analyses \& Mitigation for Federal Oil \& Gas Decisions
} 
for agencies to implement in analyzing air quality impacts and "air quality related values" ("AQRVs"), such as visibility for onshore federal oil and gas planning, leasing, or field development on federal lands. ${ }^{190}$ The MOU limits its scope to emissions associated with achieving the NAAQS and AQRVs. ${ }^{191}$ It states the emissions of hazardous air pollutants ("HAPs") and GHGs are not included. ${ }^{192}$ If EPA determines the MOU procedures have been followed the EIS's air quality analysis will be considered adequate. ${ }^{193}$ However, future laws or regulations may require additional analysis, and a satisfactory analysis does not mean impacts will be environmentally satisfactory. ${ }^{194}$ If a federal land management agency follows the best practices established by the MOU in its NEPA-based air quality and AQRVs analyses, EPA will rate the analyses "adequate," and no further NEPA-based procedure is required. ${ }^{195}$ It is not clear that EPA's oversight role will continue during the Trump administration. ${ }^{196}$

\section{NEPA Litigation Involving Climate Change Issues}

For about two decades, courts have decided cases that sought to enforce NEPA's EIS requirements in order to force the government to deal with climate change. For example, in Border Power Plant Working Group v. Dep't of Energy, a federal district court in 2003 held that an EA for a federal action contravened NEPA because it failed to disclose and analyze potential environmental impacts related to the construction of a power line transmitting electricity from new power plants in Mexico to Southern California. ${ }^{197}$ This body of caselaw includes requiring NEPA compliance for international actions impacting the U.S. ${ }^{198}$ A chronological coverage of major NEPA cases dealing with climate change follows.

Through the Nat'l Envtl. Pol'y Act Process 1 (June 24, 2011), https://www.epa.gov/sites /production/files/2014-08/documents/air-quality-analyses-mou-2011.pdf [https://perma.cc /S9RM-W6C6] [hereinafter MOU].

${ }^{190} I d$.

${ }^{191} I d$. at 12 .

${ }^{192} I d$.

${ }^{193} I d$. at 2 .

${ }^{194} I d$. at 12 .

${ }^{195}$ MOU, supra note 189, at 2, 12 .

${ }^{196}$ See, e.g., Notice Regarding Withdrawal of Obligation to Submit Information, 82 Fed. Reg. 12817, 12817 (Mar. 7, 2017).

${ }^{197}$ Border Power Plant Working Group v. Dep't of Energy, 260 F. Supp. 2d 997, 1029 (S.D. Cal. 2003).

${ }^{198}$ CEQ, Memorandum to Heads of Agencies on the Application of the National ENVIRONMENTAL Policy ACT TO PROPOSED FEDERAL ACTIONS IN THE UNited STATES With TRANSBOUNDARY EFFECTS 3 (1997), https://ceq.doe.gov/docs/ceq-regulations-and-guidance /memorandum-transboundary-impacts-070197.pdf [https://perma.cc/2YA5-72E4]. 
In Mid States Coalition for Progress v. Surface Transportation Board, the Eighth Circuit in 2003 held that the Surface Transportation Board ("STB") did not fully comply with NEPA because it failed to consider potential increases in emissions resulting from the creation of a new rail line. ${ }^{199}$ The petitioners challenged the STB's approval of 280 miles of new rail line and improvements to 600 miles of existing rail line that crossed the states of Minnesota and South Dakota in order to deliver coal from the Powder River Basin ("PRB") in Wyoming. ${ }^{200}$ The expansion and improvement raised a number of environmental issues, including a substantial increase in train traffic, a corresponding increase in noise levels in the city of Rochester, Minnesota, and reduced air quality due to an increased use of low-sulfur coal. ${ }^{201}$ The Sierra Club argued there would be a significant increase in air pollutants, including carbon dioxide. ${ }^{202}$

The court held that the direct and indirect environmental effects of a federal action causing degradation in air quality must be addressed in an EIS if the effects are "reasonably foreseeable." 203 The court found the STB "completely ignored the effects of increased coal consumption" and that the requirements within the CEQ regulations were not fulfilled; therefore "it would be irresponsible for the [STB] to approve a project of this scope without first examining the effects that may occur as a result of the reasonably foreseeable increase in coal consumption." 204 The court remanded the case to the STB.$^{205}$ The STB subsequently prepared a supplemental EIS that the Eighth Circuit found to be adequate. ${ }^{206}$

In Center for Biological Diversity v. National Highway Traffic Safety Administration, the Ninth Circuit in 2008 found numerous failures to comply with NEPA, including a failure to fully consider the aggregate impacts that GHG emissions have on climate change. ${ }^{207}$ Moreover, the court found the final rule failed to adequately examine the monetary value of

\footnotetext{
${ }^{199}$ Midstates Coalition for Progress v. Surface Transp. Bd., 345 F.3d 520, 548-50 (8th Cir. 2003).

${ }^{200} \mathrm{Id}$. at 532 .

${ }^{201} I d$. at $534-40,548$.

${ }^{202} I d$. at 548.

${ }^{203} I d$. at 549 (citing Sierra Club v. Marsh, 976 F.2d 763, 767 (1st. Cir. 1992) (finding that an effect is reasonably foreseeable when it is "sufficiently likely to occur that a person of ordinary prudence would take it into account in reaching a decision")).

${ }^{204} I d$. at 550 .

${ }^{205}$ Midstates Coalition, 345 F.3d at 556.

${ }^{206}$ Mayo Found. v. Surface Transp. Bd., 472 F.3d 545, 549, 556 (8th Cir. 2006).

${ }^{207}$ Ctr. For Biological Diversity v. Nat'l Highway Traffic Safety Admin., 538 F.3d 1172 (9th. Cir. 2008).
} 
carbon emissions. ${ }^{208}$ The petitioners, including eleven states, the District of Columbia, cities, and public interest groups, sought review of the Corporate Average Fuel Economy ("CAFE") standards promulgated by the National Highway Traffic Safety Administration ("NHTSA"), which required light trucks to meet certain fuel economy specifications. ${ }^{209}$ They alleged violations of NEPA and the Energy Policy and Conservation Act of 1975. ${ }^{210}$

The court was critical of the cumulative analysis found in the EA because the new CAFE standards did not consider how emissions would impact climate change, nor would the standards offset the emissions resulting from a greater number of light trucks. ${ }^{211}$ Under the cumulative impacts regulation, agencies must review the current action together with "other past, present, and reasonably foreseeable future [government] actions." 12 The court found that, pursuant to NEPA, agencies should conduct cumulative impacts analysis on GHG emissions' effect on climate change. ${ }^{213}$ The Ninth Circuit concluded the EA was "markedly deficient in its attempt to justify the refusal to prepare a complete environmental impact statement" and remanded the case to NHTSA to prepare either an updated EA or, if needed, an EIS. ${ }^{214}$

In South Fork Band v. U.S. Department of the Interior, the Ninth Circuit in 2009 held that indirect effects that impact air quality must be considered under NEPA. ${ }^{215}$ Indirect effects include those "caused by the action, [and] later in time or further removed in distance, [but] still reasonably foreseeable." ${ }^{" 16}$ Because the Supreme Court has held that carbon dioxide is a pollutant, its emissions would appear to be subject to the indirect effects rule. ${ }^{217}$

Center for Biological Diversity v. U.S. Department of the Interior, decided by the D.C. Circuit in 2009, involved a challenge to the Federal Leasing Program under the Outer Continental Shelf Lands Act ("OCSLA") involving offshore oil and gas development in the waters off of Alaska's coast. ${ }^{218}$ The case included both NEPA and Endangered Species Act ("ESA")

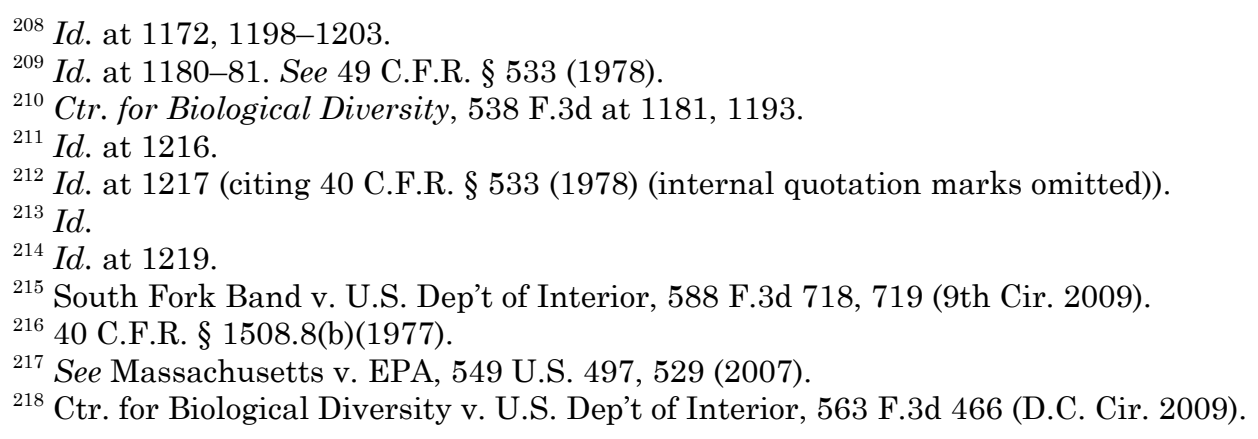


claims. ${ }^{219}$ The court ruled that the challengers had procedural standing under both OCSLA and NEPA, but that some of the claims were not ripe for review. ${ }^{220}$ The court then vacated and remanded the Leasing Program. ${ }^{221}$ Petitioners alleged violations of both OCSLA and NEPA because the Department of the Interior "failed to consider both the economic and environmental costs of the greenhouse gas emissions associated with the Program and the effects of climate change on OCS areas." ${ }^{222}$

The court, in denying a substantive right to standing, distinguished Massachusetts $v$. EPA by finding that case was limited to a sovereign (Massachusetts) suing to protect its own interests. ${ }^{223}$ Petitioners' substantive theory that climate change in the Arctic environment may occur due to the DOI's Leasing Program was not an injury-in-fact that met the requirements of Article III because it was not actual or imminent as required by the law of standing. ${ }^{224}$ In addition, since humanity as a whole shares in the repercussions of climate change, the alleged injury to the petitioners was too broad to warrant standing. ${ }^{225}$ The NEPA-based claims were not ripe because the obligation to comply with NEPA had not yet occurred. ${ }^{226}$ The OCSLA-based climate change claims were also dismissed. ${ }^{227}$ However, the Leasing Program was vacated based on the challenge to the environmental sensitivity rankings, which resulted in the Leasing Program being remanded to the Secretary for reconsideration. ${ }^{228}$

In WildEarth Guardians v. Jewell, environmental organizations in 2013 used NEPA to challenge BLM's decision to authorize coal leases in Wyoming. ${ }^{229}$ Antelope Coal, LLC, had submitted an application to BLM in 2005 seeking a competitive lease sale for a parcel of federal land. ${ }^{230}$ BLM's March 2010 ROD split the land into two parcels (the West Antelope II tracts), and authorized separate competitive bidding processes for the leases. ${ }^{231}$ WildEarth Guardians and other environmental groups challenged BLM's decision to approve leases for the West Antelope II tracts

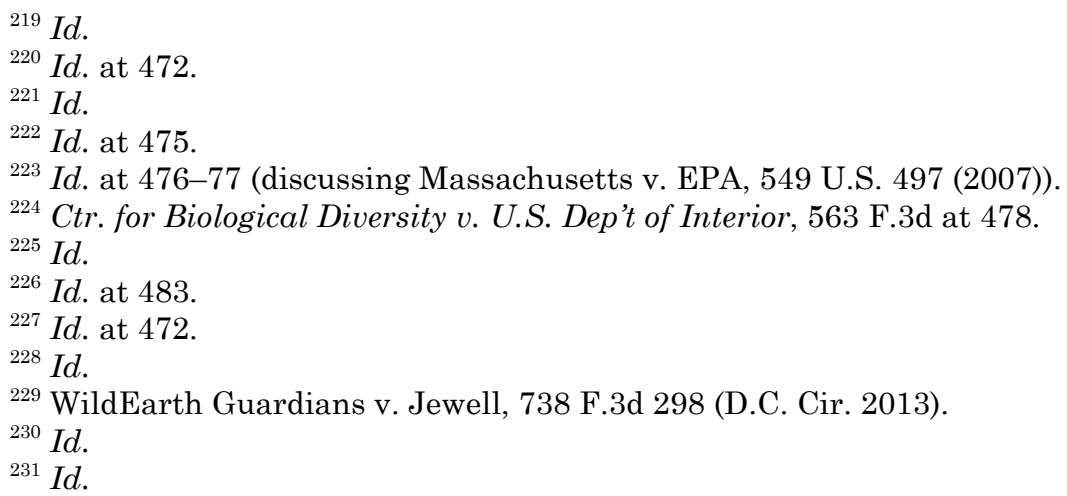


for lease based on alleged deficiencies in the FEIS that accompanied the ROD. ${ }^{232}$ The district court granted summary judgment to the defendants, rejecting some of the plaintiffs' arguments on the merits, and preventing the plaintiffs from raising another argument because they lacked standing on that claim. ${ }^{233}$ On appeal, the D.C. Circuit concluded there was standing, but the petitioners lost on the merits, and the judgment of the district court was affirmed. ${ }^{234}$

EPA published a FEIS of nearly 500 pages in 2008, which included BLM's answers to public comments submitted on the draft EIS. ${ }^{235}$ On March 25, 2010, BLM approved Antelope Coal's application in a ROD, and divided the land into two lots, with each to be leased according to a competitive bidding process. ${ }^{236}$ Antelope Coal successfully bid for both leases, and in 2011, the leases went into effect. ${ }^{237}$ Appellants claimed that the BLM ROD failed to sufficiently consider heightened levels of local pollution, as well as climate change. ${ }^{238}$ The court held the environmental organizations may challenge all FEIS shortcomings because each error represented a procedural injury related to plaintiffs' "members' recreational and aesthetic injuries." 239 The court also considered only two of the appellants' challenges to the FEIS worth discussing. ${ }^{240}$

The court looked at whether BLM had taken a "hard look" at the impact its leasing decision could have on climate change. ${ }^{241}$ BLM had included a detailed discussion of the current scientific consensus on climate change and how coal mining adds to it. ${ }^{242}$ BLM predicted that only 0.63 percent of $\mathrm{CO}_{2 \mathrm{e}}$ emissions statewide could be connected to anticipated GHG emissions at the Antelope Mine, although BLM admittedly speculated about future emissions projections. ${ }^{243}$ Moreover, BLM noted possible inaccuracies in these future emissions projections, and did not preclude the possibility of new regulatory and technological developments altering those numbers. ${ }^{244}$ The court quoted draft guidance from the CEQ saying

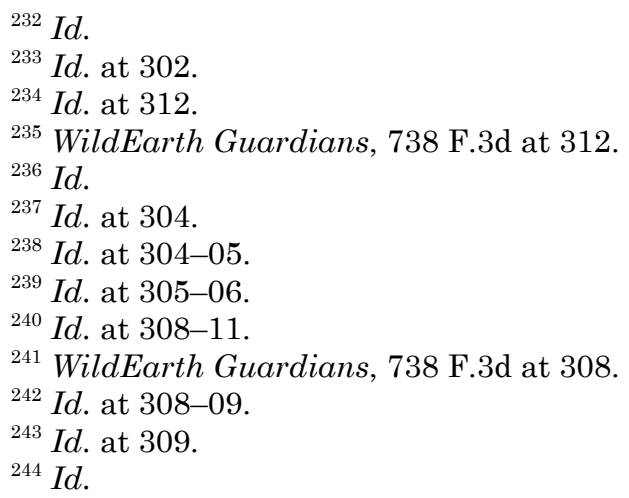


"it is not currently useful to attempt to link specific climatological changes, or the environmental impacts thereof, to the particular projects or emissions." ${ }^{45}$ The court found that, "[b] ecause current science does not allow for the specificity demanded by the Appellants, the BLM was not required to identify specific effects on the climate in order to prepare an adequate EIS." "246 The court also considered the need to take a "hard look" at local air pollution impacts, but this issue is not related to the subject of this Article. ${ }^{247}$ The court concluded that "[t]he NEPA process involves an almost endless series of judgment calls," and "the line-drawing decisions necessitated by the NEPA process are vested in the agencies, not the courts." 248

In WildEarth Guardians v. BLM, the U.S. District Court of the District of D.C. in 2014 decided a case in which environmental organizations contested a BLM-granted coal mining lease on public lands in Wyoming. ${ }^{249}$ The case was based on alleged violations of NEPA and the Federal Land Policy Management Act. ${ }^{250}$ The environmental organizations were unsuccessful, but the court did rule on the FEIS's treatment of climate change. The plaintiffs claimed that BLM did not complete a proper analysis of the direct $\mathrm{CO}_{2}$ emissions from the leases, the aggregate climate effects of the two leases considered in light of existing leases on the same lands, or the aggregate indirect effects from combustion resulting from operations authorized by the leases. ${ }^{251}$ However, the court rejected the plaintiffs' challenges because their proposed level of analysis "was neither possible based on current science, nor required by law." ${ }^{252}$

BLM recognized that GHGs would be released. Its FEIS provided annual data for 2007 on GHG emissions at mines in the South Gillette area, and then projected how coal mining operations at the two leased tracts would impact anticipated annual GHG emissions. ${ }^{253}$ BLM's analysis predicted that emissions from coal mining in the South Gillette area, taking the four proposed leases into consideration, would together represent 1.7

\footnotetext{
${ }^{245}$ Id. (citing Joint Appendix at 1281, WildEarth Guardians v. Jewell, 738 F.3d 298 (D.C. Cir. 2013) (Nos. 12-5300, 12-5312)).

${ }^{246}$ Id. at 309 .

${ }^{247}$ WildEarth Guardians, 738 F.3d at 311-12.

${ }^{248}$ Id. (quoting Duncan's Point Lot Owner's Ass'n, Inc. v. Fed. Energy Reg. Comm'n, 522 F.3d 371, 376 (D.C. Cir. 2018)) (internal quotation marks omitted).

${ }^{249}$ WildEarth Guardians v. BLM, 8 F. Supp. 3d 17 (D.D.C. 2014).

${ }^{250} \mathrm{Id}$. at 17 .

${ }^{251} I d$. at $34-35$.

${ }^{252} \mathrm{Id}$

${ }^{253} \mathrm{Id}$
} 
percent of the state of Wyoming's projected $2020 \mathrm{CO}_{2}$ emissions. ${ }^{254} \mathrm{BLM}$ also estimated the $\mathrm{CO}_{2}$ emissions from South Gillette area coal mining and pending leases from other PRB mines. ${ }^{255}$ The EIS estimated that $\mathrm{CO}_{2}$ emissions resulting from coal combustion from all PRB mines for the year 2006 represented 33.6 percent of the total $\mathrm{CO}_{2}$ emissions resulting from coal combustion nationwide. ${ }^{256} \mathrm{BLM}$ also included studies looking at how the western U.S. could possibly be impacted by global warming and climate change, but stated, "there are uncertainties regarding how climate change may affect different regions." 257

Because the nature of climate science makes it difficult to establish specific connections between certain GHG emissions and corresponding climate impacts, the court found that it was permissible for BLM to consider GHG emissions as a proportion of statewide and nationwide emissions. ${ }^{258}$ The court cited to draft CEQ guidance referenced in West Antelope II, which stated that NEPA analyses did not need to attempt to connect specific climate changes or impacts to the emissions of specific projects, but rather, the emissions estimations "can serve as a reasonable proxy for assessing potential climate change impacts." ${ }^{259}$ For these reasons, the court concluded that the FEIS adequately discussed climate impacts. ${ }^{260}$

In 2014, High Country Conservation Advocates v. U.S. Forest Service was decided by the United States District Court for the District of Colorado. ${ }^{261}$ The case involved environmental organizations seeking review of three agency decisions that approved of mining exploration in roadless sections of public lands that the Forest Service and BLM jointly managed. ${ }^{262}$ The petitioners alleged that the decisions violated NEPA ${ }^{263}$ The court found that the Lease Modification FEIS insufficiently disclosed the effects of GHG emissions; that the Colorado Roadless Rule (“CRR”) FEIS did not disclose the GHG emissions associated with mining operations; and that the CRR FEIS also inadequately disclosed the GHG emissions resulting from combusting coal that would be mined. ${ }^{264}$ The court granted

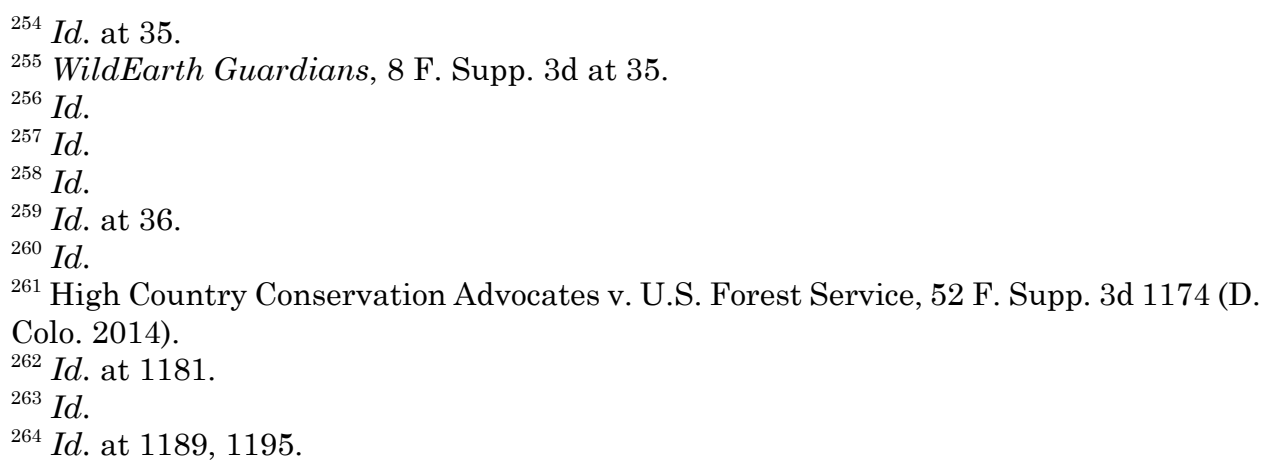


an injunction, and the government's Exploration Plan was vacated. ${ }^{265}$ The court deemed the agencies' evaluation of costs related to the mine's GHG emissions to be arbitrary and capricious. ${ }^{266}$

An EIS must disclose and evaluate all of the effects of a proposed action-"whether direct, indirect, or cumulative"-to include "ecological[,] . . economic, [and] social" impacts of a proposed action. ${ }^{267}$ While the agencies discussed the possibility of methane and carbon dioxide emissions, the court held the agencies needed to discuss the effects of these emissions. ${ }^{268}$ Rather, the agencies categorically denied that such an analysis would be feasible. ${ }^{269}$ Instead, the court noted, the agencies could have used the social cost of carbon protocol tool. ${ }^{270}$ This protocol was detailed in a Technical Support Document put out by the IWG on Social Cost of Carbon, and is designed to calculate a project's impact on costs related to global climate change. ${ }^{271}$ The court therefore concluded that the FEIS failed to use this tool based on "factually inaccurate justification[s]."272

The court found that, while NEPA does not mandate that agencies conduct a cost-benefit analysis, the decision to quantify the positive aspects of the leases and deny that an analogous inquiry into costs was possible, despite the fact that such an analysis was possible (and had been included in a prior draft EIS), was arbitrary and capricious. ${ }^{273}$ Assessing the economic impacts of GHGs is difficult at best, but any "hard look" must incorporate a "hard look" at whether such analysis, however indefinite, would provide for a more informed means of estimating these impacts than simply ignoring them. ${ }^{274}$

The plaintiffs challenged the CRR FEIS's failure to include any estimate of how coal combustion would impact GHG emissions. ${ }^{275}$ The court agreed that the agencies could not claim that it was overly speculative to predict data for coal combustion emissions, ${ }^{276}$ especially when the agencies had predicted emissions from prospective mining and coal combustion in

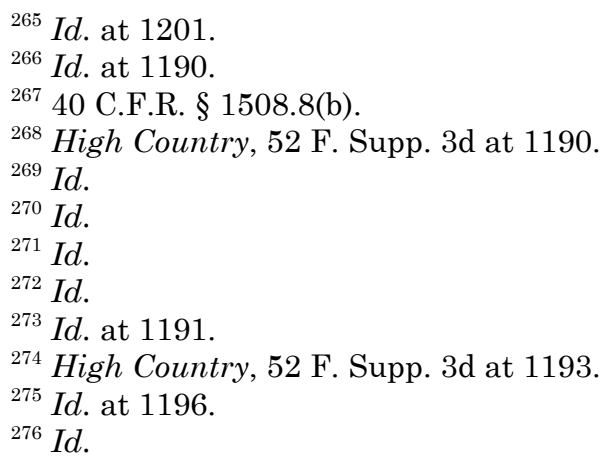


other instances. ${ }^{277}$ Within the same FEIS, the court concluded, the agency could not claim "it would be too speculative to estimate emissions from 'coal that may or may not be produced' from 'mines that may or may not be developed" while at the same time disclosing detailed data on the amount of coal those mines would produce. ${ }^{278}$

The court found that the agencies' argument that new technology could lower carbon emissions originating from future coal combustion failed to qualify as a "hard look." "279 Agencies cannot speculate that future technologies could possibly be invented to mitigate these effects. ${ }^{280}$

The agencies' last argument was that the overall GHG emissions from combustion would be the same regardless of these new operations because if these operations did not occur there, consumer demand would drive the coal to be mined elsewhere because coal is "a global commodity." ${ }^{281}$ Thus, if the coal does not originate from the North Fork Valley of Colorado, the overall GHG emissions that can be attributed to combustion would still be the same. ${ }^{282}$

However, the court rejected this argument. ${ }^{283}$ The court found that producing coal in the North Fork would boost the amount of inexpensive low-sulfur coal available, thus impacting the demand for coal as compared to alternate fuel sources. ${ }^{284}$ Thus, coal that otherwise never would have been mined would be burned. ${ }^{285}$ The agencies were therefore required to analyze this effect because it was reasonably foreseeable, "even if the precise extent of the effect [was] less certain."286

In 2017, the D.C. Circuit decided Sierra Club v. FERC. ${ }^{287}$ The case involved environmental groups and landowners challenging the Federal Energy Regulatory Commission's ("FERC") issuance of a certificate of public convenience and necessity permitting three interstate natural gas pipelines to be built in the southeastern U.S. ${ }^{288}$ The petitioners argued the environmental assessment was inadequate. ${ }^{289}$ The court agreed that

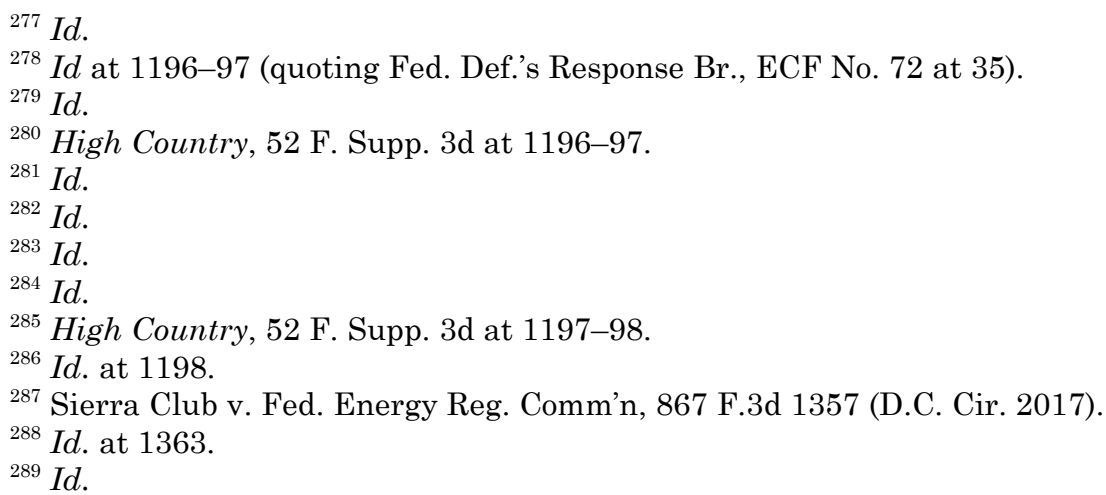


the EIS did not sufficiently discuss emissions resulting from burning the gas transported by the pipelines. ${ }^{290}$ The court granted Sierra Club's petition for review and remanded to bring the EIS into conformity, while finding that the FERC acted properly in all other respects. ${ }^{291}$

Landowners challenged the pipelines because of the associated seizure of their property, while environmental groups feared that burning the natural gas would accelerate climate change ${ }^{292}$ Communities objected to the pipelines too, claiming "that pipeline facilities [would] be built in

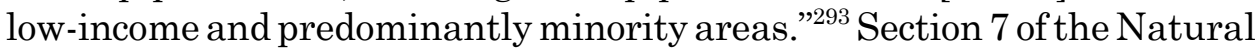
Gas Act gives FERC jurisdiction to approve or deny the construction of interstate natural gas pipelines. ${ }^{294}$ FERC conducted an analysis of environmental impacts related to the proposed project, released a draft of the analysis in September 2015, and released the final version in December of the same year. ${ }^{295}$ It issued Section 7 certificates and approved construction of the proposed project, so long as the construction complied with certain conditions. ${ }^{296}$ The pipeline construction followed in August $2016 .{ }^{297}$ The environmental groups and the landowners petitioned for review of the Certificate Order and the Rehearing Order. ${ }^{298}$ The Sierra Club argued the EIS did not properly assess the project's GHG emissions contribution. ${ }^{299}$ The court found that the Sierra Club members had standing to object to the certification because they alleged concrete injuries and because the certification was based on an insufficient EIS. ${ }^{300}$ An EIS can be deficient even if it is not "directly tied to the members' specific injuries." ${ }^{01}$

The EIS serves dual purposes; ${ }^{302}$ first, it requires the agency to scrutinize the environmental impacts of its decisions and to consider alternatives to its proposed actions. ${ }^{303}$ Second, the EIS ensures the public is informed of the potential consequences by requiring disclosure. ${ }^{304}$

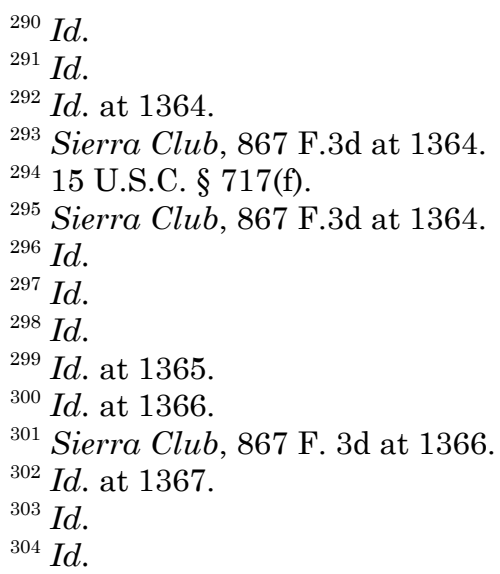


"NEPA directs agencies to only look hard at the environmental effects of their decisions, and not to take one type of action." ${ }^{305}$ The main issue, then, was whether an EIS would undermine the public comment and make the decision-making process less informed because of the EIS's shortcomings. ${ }^{306}$ The court also discussed the environmental justice issues, which were not germane to the climate change issue, and concluded there were no NEPA violations. ${ }^{307}$

The court then addressed whether an EIS should include a discussion of the pipelines' "downstream" effects and their cargo, and if so, to what extent. ${ }^{308}$ It concluded that FERC was at least required to calculate estimates of the power plant carbon emissions the pipeline would facilitate. ${ }^{309}$ A NEPA review must consider the direct effects and the indirect environmental effects of a project. ${ }^{310}$ The phrase "reasonably foreseeable" is the key, which describes effects "sufficiently likely to occur that a person of ordinary prudence would take [them] into account in reaching a decision." ${ }^{111}$ The court recognized the amount of gas burned in the power plants was not only reasonably foreseeable, but was, in fact, "the project's entire purpose." ${ }^{12}$ The court reasoned that it was likewise foreseeable that burning natural gas would also emit carbon compounds that add to climate change. ${ }^{313}$

The court distinguished Dep't of Transportation v. Public Citizen, in which the Supreme Court held that an agency does not have to analyze environmental effects when it has no legal power to prevent those effects because it does not require a decision whether to inform the public. ${ }^{314}$ The court applied this rationale to cases concerning liquefied natural gas ("LNG") licenses. ${ }^{315}$ One common issue among these cases was whether FERC needed to analyze the effects on climate change of exporting natural gas when it licensed physical upgrades for LNG terminals. ${ }^{316}$ The court concluded that because "FERC had no legal authority to consider

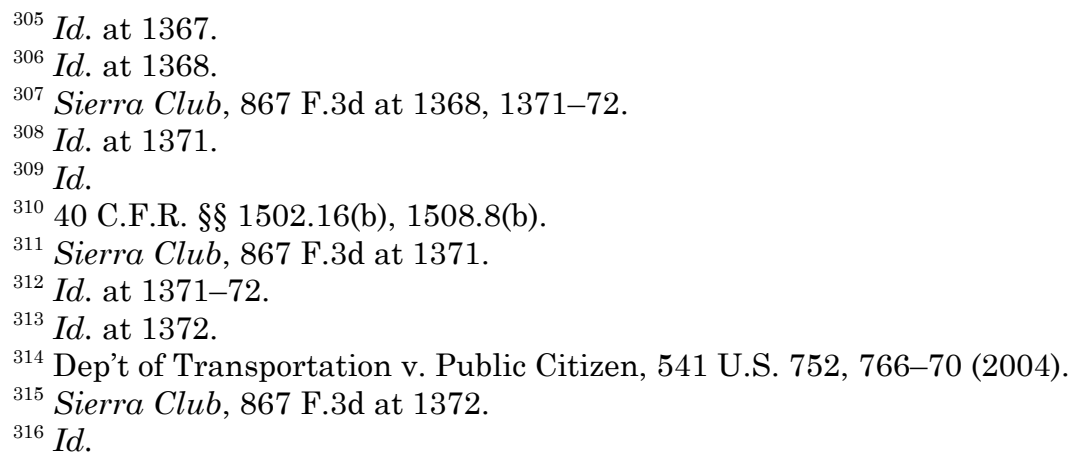


the environmental effects of those exports," no NEPA obligations to analyze those effects arose. ${ }^{317}$ "An agency has no obligation to gather or consider environmental information if it has no statutory authority to act on that information." ${ }^{18}$

Congress made a broad delegation to FERC to evaluate applications for interstate pipelines considering public convenience and necessity factors. ${ }^{319}$ Because the agency may deny applications based on their environmental effects, the agency would thus become a legally relevant cause of the environmental harms arising from the pipelines it approved.$^{320}$ In this case, the court reasoned that FERC calculated the amount of gas flowing through the pipelines, so they were capable of using that number to predict GHG emissions from the power plants. ${ }^{321}$

The court concluded that the EIS "should have either given a quantitative estimate of the downstream greenhouse emissions that will result from burning the natural gas that the pipelines will transport or explained more specifically why it could not have done so." ${ }^{322}$ The court reasoned GHG emissions were indirect byproducts of the project, and the agency had the authority to permit the project, which meant it also had the legal authority to mitigate impacts of that project. ${ }^{323}$ The EIS had to discuss the aggregate incremental effect of the agency action in conjunction with past, present, and reasonably foreseeable future actions, in addition to the impact of indirect effects. ${ }^{324}$ FERC should have "compared the emissions from this project to emissions from other projects, to total emissions from the state or the region, or to regional or national emissionscontrol goals." ${ }^{325}$ The court questioned how FERC, in the absence of such comparisons, could have conducted adequately informed decision-making or public comment on the GHG impacts of the project. ${ }^{326}$

While the court did not require FERC to put a number to GHG emissions when there are indirect effects, it suggested that the agency's failure to provide even an explanation for its lack of a calculation was unsatisfactory. ${ }^{327}$ In the court's view, the fact that emissions estimates

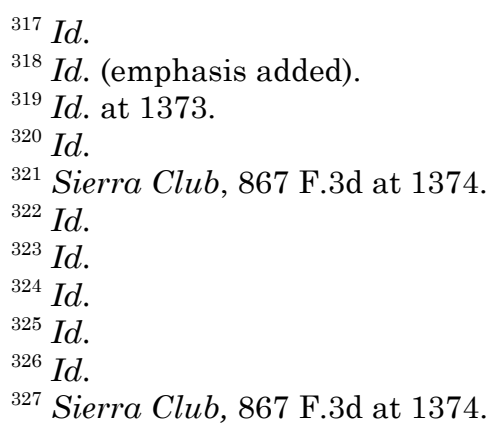


could have been based on assumptions did not preclude their inclusion in the EIS because those assumptions could have been disclosed to the public. ${ }^{328}$ Moreover, FERC is not excused "from making emissions estimates because the [project's] emissions might be partially offset by reductions elsewhere." ${ }^{329}$ The EIS must include beneficial and detrimental effects. ${ }^{330}$ Even if a project is subject to state or federal air permitting processes, "the existence of permit requirements overseen by another federal agency or state permitting authority cannot substitute for a proper NEPA analysis." ${ }^{331}$ In addition, the court held that FERC should explain in the EIS whether the Social Cost of Carbon tool should be utilized. ${ }^{332}$ The court then vacated and remanded the case to FERC for it to prepare an EIS consistent with the opinion. ${ }^{333}$

Circuit Judge Brown concurred in part and dissented in part. ${ }^{334}$ He dissented from the opinion to vacate and remand on the issue of downstream greenhouse emissions. ${ }^{335}$ His position was that an agency does not need to discuss in its EIS indirect environmental effects that occur as a result of a separate agency issuing a license ${ }^{336}$ FERC therefore has latitude to determine whether it should analyze environmental effects based on whether its decision-maker will be better informed from the inclusion of that analysis. ${ }^{337}$ Here, Judge Brown pointed out that FERC acted within its discretion in deciding not to analyze the downstream effects of the proposed pipelines because the analysis of those effects would not add to the decision-making process even if a causal link could be established. ${ }^{338}$

The causal relationship required by the statute is a "close" one that is "akin to proximate cause in tort law." ${ }^{339}$ Here, the Commission's action was not significant enough to establish its causal relationship to the environmental effects in question because the agency was "powerless to prevent" those effects; those effects therefore are not required under

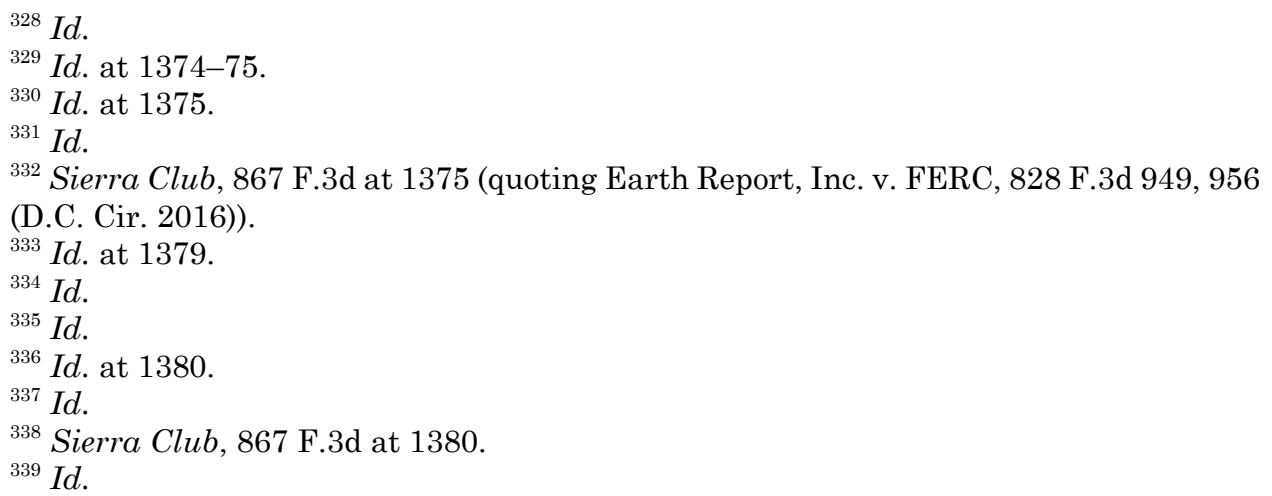


NEPA analysis. ${ }^{340}$ Here, FERC was not responsible for whether the power plants causing those GHGs were ever created or built. ${ }^{341}$

Judge Brown cited multiple precedents where downstream environmental effects could not be attributed to a commission because those effects only came into existence because another agency issued a license, giving that agency oversight of the associated environmental effects. ${ }^{342}$ Power plants, and their associated emissions, he noted, only come into existence in Florida with the approval of the Board. ${ }^{343}$ Therefore, "NEPA does not require FERC to address indirect environmental effects resulting from the Board's licensing decision." ${ }^{344}$ The Commission, therefore, did not have this authorization and so was not responsible for analyzing the emissions effects that authority would create, including downstream GHG emissions. ${ }^{345}$ "Accordingly, the Commission was not obligated under NEPA to discuss downstream greenhouse gas emissions." 346

On June 14, 2018, in San Juan Citizens Alliance v. BLM, the U.S. District Court for the District of New Mexico decided a challenge to oil and gas leases issued in 2015 for thirteen parcels of federal land totaling 19,788 acres in New Mexico based on alleged violations of NEPA. ${ }^{347}$ The court granted the plaintiffs part, and denied part, of the relief they requested. ${ }^{348}$ The case involved an EIS issued by the Forest Service in 2008 that was supplemented in 2012 and reviewed in 2013 when the Forest Service found it was adequate under NEPA. ${ }^{349}$ BLM then issued a Decision Record and EA in 2015 that tiered to and incorporated the Forest Service's earlier evaluations. ${ }^{350}$ After BLM issued the leases, plaintiffs challenged the action claiming a variety of NEPA violations. ${ }^{351}$

Plaintiffs have a difficult challenge to overcome in NEPA-based cases. If the adverse environmental effects of a proposed action are adequately identified and evaluated, the agency may decide other values outweigh the environmental costs of the project. Here, plaintiffs claimed

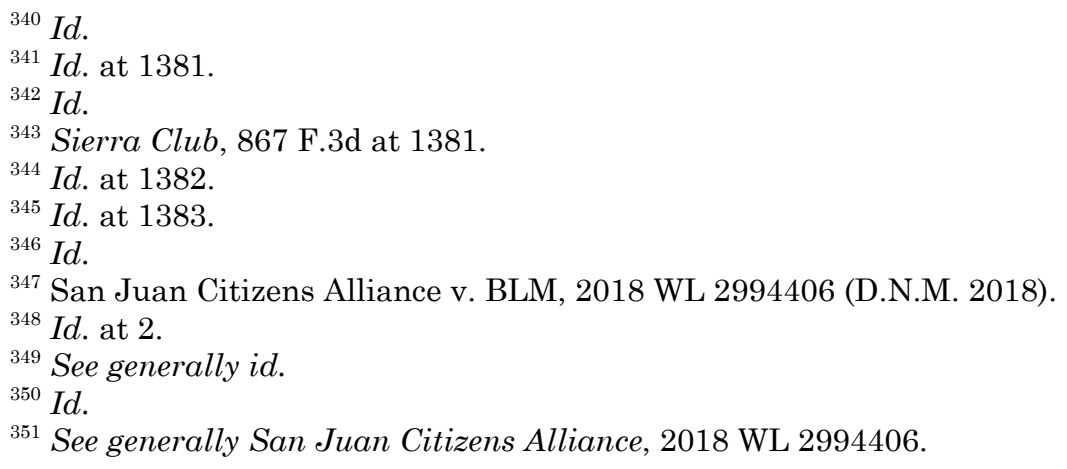


the agencies did not satisfy the hard look standard by failing to consider "direct, indirect, and cumulative impacts of the oil and gas leasing." ${ }^{352}$ They argued that BLM failed to consider: "(1) greenhouse gas emissions and climate change; (2) air quality, (3) water resources-including the impacts to water quantity, groundwater quality, and surface water quality; and (4) the cumulative impacts of lease development." ${ }^{353}$

BLM's Decision Record concerning GHGs stated that it only considered GHG "emissions associated with exploration and production of oil and gas." ${ }^{554}$ It did not evaluate emissions from oil and gas consumption. ${ }^{355}$ BLM's position was that GHG emissions from consumption of oil and gas do not constitute a direct effect that must be assessed under NEPA. ${ }^{356}$ Although BLM did not analyze consumption emissions as a direct effect, it did evaluate it as a cumulative effect. ${ }^{357}$ In its analysis, BLM estimated the total potential emissions from field production at the point when 118 wells were estimated to have produced 11,611 metric tons of oil and gas per year (0.0018 percent of U.S. GHG emissions when the leases were fully developed). ${ }^{358}$ BLM's Decision Record stated its finding that the cumulative effects of the lease sales on climate change would be minimal-the alternative actions would lead to the same climate change effects as taking no action. ${ }^{359} \mathrm{BLM}$ also included in this assessment effects of oil and gas development found in other reports. ${ }^{360}$ However, BLM could not "associate an action's contribution in a localized area to impacts on global climate change." ${ }^{\prime 61}$ Lastly, BLM tiered its Decision Record to the Forest Service's earlier impacts statement which had estimations of the oil and gas emissions correlated with the new leases." ${ }^{362}$ BLM stated that consumption is not an "indirect effect of oil and gas production because production is not a proximate cause of GHG emissions resulting from consumption." 363 The court criticized the statement as "contrary to the reasoning in several persuasive cases," which held an

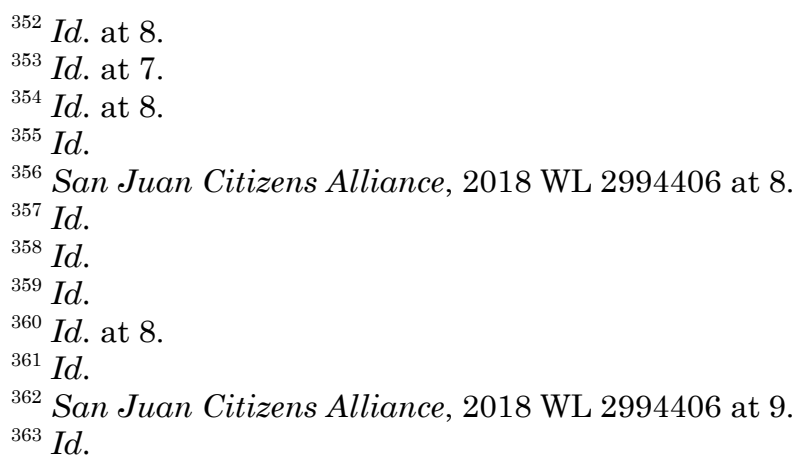


agency's decision allowing natural resource extraction indirectly caused combustion emissions. ${ }^{364}$ In those cases, the court held that either the EIS had to quantify downstream GHGs from burning natural gas or explain why the agency could not have made such a calculation. ${ }^{365}$ "For actions such as a Federal lease sale of coal for energy production, the impacts associated with the end-use of the fossil fuel being extracted would be ... reasonably foreseeable." 36640 C.F.R. $\$ 1508.8(b)$ states that indirect effects of an action are effects that "are caused by the action and are later in time or farther removed in distance, but are still reasonably foreseeable." ${ }^{367}$ For these reasons, the court held it erroneous that BLM failed to assess impacts of downstream oil, gas, and coal combustion that would develop under the proposed projects. ${ }^{368}$ The court concluded that BLM's failure to estimate the amount of greenhouse gas emissions from combustion of the oil and gas produced from these leases was arbitrary. ${ }^{369}$ Therefore, it ordered that BLM must reanalyze the potential impact of such GHGs on climate change. ${ }^{370}$ The failure of BLM to quantify and analyze the impacts of the downstream GHG emissions resulted in the case being remanded. ${ }^{371}$ The court also held that BLM failed to conduct a cumulative effects analysis as required by 40 C.F.R. $\S 1508.7{ }^{372}$ While the impact of the leasing may be insignificant when taken alone, "the broader, significant 'cumulative impact' which must be considered by an agency," may be significant. ${ }^{373} \mathrm{BLM}$ 's unjustified conclusion that this proposed action would not lead to greater or different climate impacts than taking no action, and that the impact was therefore minimal, failed to satisfy the regulation's requirements. ${ }^{374}$ Thus, the court required BLM to revise its cumulative impacts analysis.

On June 19, 2018, Western Organization of Resource Councils v. Zinke was decided by the D.C. Circuit. ${ }^{375}$ Plaintiffs in this case sought to

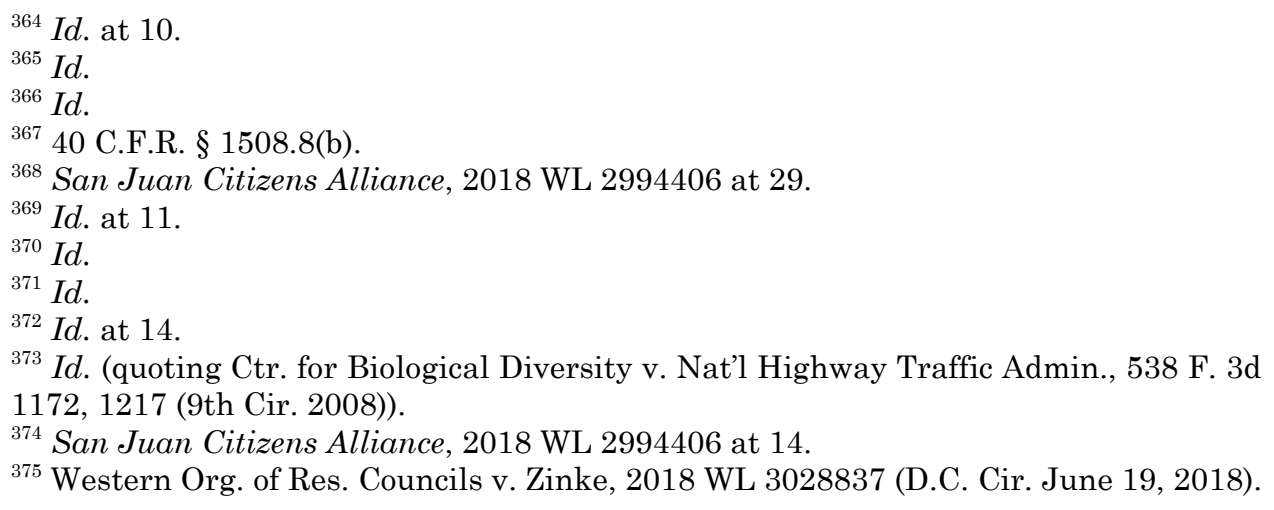


compel the Secretary of the Interior to update the Federal Coal Management Program's PEIS. ${ }^{376}$ The appellants wanted the Secretary to update the PEIS because it had been produced prior to a substantial change in the understanding of the environmental impacts of coal leasing. ${ }^{377}$ The court held that there was no binding duty created by the PEIS that required the Secretary to update it. ${ }^{378}$ The PEIS had been published in 1979 and was supplemented in 1985 with a finding that continued coal leasing would have no long-term impacts on air quality. ${ }^{379}$ However, no new action respecting the program was planned. ${ }^{380}$ The appellants claimed that "tens of thousands of peer-reviewed scientific studies have identified the causes and consequences of continued atmospheric warming and showed that coal combustion is the single greatest contributor to the growing concentration of greenhouse gases in the atmosphere." ${ }^{881}$ However, the court held that neither NEPA nor the APA require the PEIS to be updated. ${ }^{382}$ In administering the Coal Program, each lease the agency issued would constitute a new "federal action," 383 and the DOI accordingly prepared separate EISs or EAs prior to issuing each new proposed lease. ${ }^{384}$ However, even though the discrete EISs analyzed emissions related to the lease, they failed to cover the impacts on the global climate by the plan as a whole. ${ }^{385}$ DOI admitted the PEIS was outdated and relevant new information on climate impacts existed, but it claimed there was no NEPA obligation because no action based on the 1979 PEIS was being considered. ${ }^{386}$ The court held that the "appellants have failed to identify any specific pending action, apart from the Program's continued existence, that qualifies as a 'major Federal action' under NEPA." ${ }^{87}$ The court considered the action completed in 1979, at the time the department published the ROD and adopted the rule. That action was completed when the DOI "issued the ROD and promulgated the final rule in 1979."

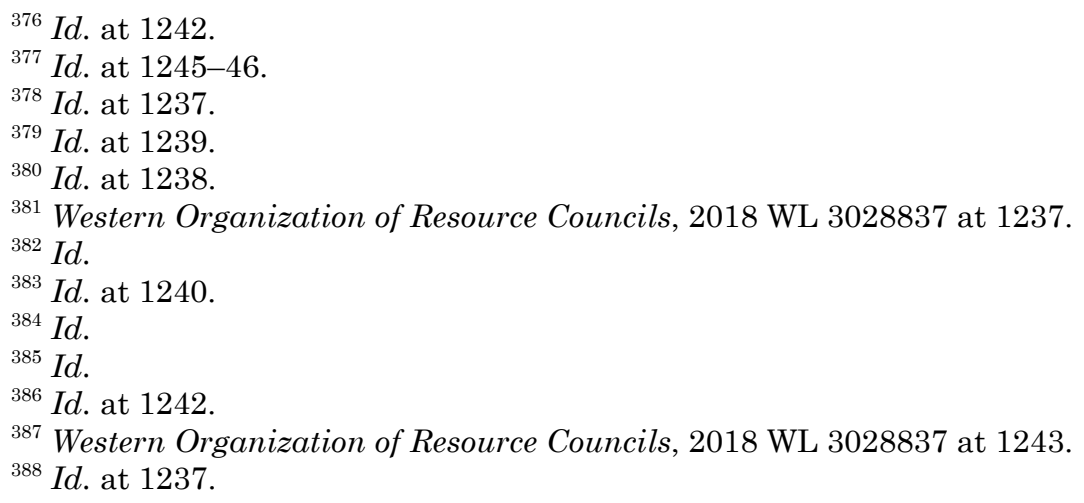


Because no "major Federal action" remains concerning the Federal Coal Management Program, the court held that NEPA did not impose a duty to supplement the PEIS. ${ }^{389}$

\section{DISCUSSION}

NEPA was enacted to develop better information for federal agency decision-makers that will lead to better decisions by considering the environmental impact of their actions. ${ }^{390}$ The cases discussed above show the agencies frequently fail to accomplish this goal. The ten cases discussed resulted in the federal government losing six cases, and one was dismissed for lack of standing. ${ }^{391}$ The agencies appear to resist full NEPA compliance because of the substantial cost in time and money. If NEPA compliance requires an analysis of climate change impacts, especially if the analysis includes dealing with indirect effects as well as cumulative impacts, costs of compliance could increase substantially. ${ }^{392}$ Whether the increased costs and other challenges of NEPA compliance would produce information that results in better decisions is an issue to be considered. However, such concerns may not be relevant. Elections have consequences.

The ideal agency executive should welcome additional information. Because NEPA is primarily a procedural statute its effectiveness depends on the integrity of the decision-maker. The statute's viability depends on federal agencies wanting to know how their actions will affect climate change and how climate change will affect the federal agency. That information needs to be integrated with the process for carrying out the agency's primary mission. However, NEPA cannot protect the environment if the president and the heads of the federal agencies dealing with the environment and natural resources are committed to expanding fossil fuel production without concern for the related climate change impacts. President Trump's efforts to expand the use of fossil fuels began with his choices for Secretaries of the Interior, Energy, and State, as well as the Administrator and Acting Administrator of EPA. Each have a record of strong support for the fossil fuel industry, as well as a record of antipathy toward environmental protection. The Trump administration's implementation of the air pollution program (including climate change efforts)

\footnotetext{
${ }^{389} \mathrm{Id}$.

${ }^{390}$ McAliley, supra note 63, at 10197.

${ }^{391}$ Supra Part VI.

${ }^{392}$ McAliley, supra note 63, at 10200.
} 
demonstrates a continuing effort to reduce federal air environmental protection efforts. ${ }^{393}$ The Republican-controlled 115th Congress has supported the president's deregulation efforts, which results in both the CAA's public health protection mandate and its ecosystem protection mandate being subordinated to a policy intended to minimize the cost to industry of environmental regulation. ${ }^{394}$

The president's attitude concerning the CEQ was displayed on December 21, 2017, when he nominated Kathleen Hartnett White to serve as the chair of the CEQ.${ }^{395}$ She had been the former commissioner of the Texas Council on Environmental Quality, but her nomination was controversial because of her views questioning whether climate change is related to the emissions from the use of fossil fuels. ${ }^{396}$ Her nomination was blocked by the Senate, but on January 8, 2018, President Trump once again nominated her. ${ }^{397}$ His initial choice for his chief advisor on environmental matters was a person who does not believe in the consensus position of scientists concerning both conventional air pollution and climate change. As the controversy over her nomination continued, the president withdrew Ms. White's nomination in February 2018, and in June 2018, the president nominated Mary Neumayr, a former House Energy and Commerce Committee energy counsel. ${ }^{398}$ While counsel for the Committee,

${ }^{393}$ Since becoming the EPA's Administrator Scott Pruitt has worked to undermine more than thirty rules including at least ten air pollution rules. He has also worked to downsize the Agency's workforce and budget, weaken EPA's science capabilities, and scale back oversight of state programs. Umair Irfan, Scott Pruitt is slowly strangling the EPA, Vox (last updated Mar. 8, 2018 8:19 AM), https://www.vox.com/energy-and-environment/2018/1/29/16684 952/epa-scott-pruitt-director-regulations [https://perma.cc/R6UC-GM4Y].

${ }^{394}$ Chris D'Angelo, Republicans Look To Block EPA From Tackling Climate Change, HuFFINGTON POST (Feb. 3, 2017), https://www.huffingtonpost.com/entry/gary-palmer-bill-epa _us_58949441e4b0406131365066 [https://perma.cc/HWD2-XP35].

${ }^{395}$ Brian Dennis \& Chris Mooney, Trump taps Climate Skeptic for top White House environmental post, WASHINGTON POST (Oct. 13, 2017), https://www.washingtonpost.com/news /energy-environment/wp/2017/10/13/trump-taps-climate-skeptic-for-top-white-house-envi ronmental-post/?noredirect=on\&utm_term=.a05e7ab21ac6 [https://perma.cc/DX7A-P4C7]. ${ }^{396}$ Tiffany Stecker, Energy, Environment Nominees Hit Snag in Senate's Year-End Wrapup, BLOOMBERG ENERGY AND ClIMATE REP.(Dec. 22, 2017), https://bnanews.bna.com/environ ment-and-energy/energy-environment-nominees-hit-snag-in-senates-year-end-wrapup [https://perma.cc/V8JW-637N].

${ }^{397}$ Rob Tricchinelli \& Dean Scott, Trump Renominates Candidates for Environmental, Safety Posts, BLOOMBERG ENERGY AND Climate REPORT(Jan. 8, 2018), https://news.bloom bergenvironment.com/environment-and-energy/trump-renominates-candidates-for-envi ronmental-safety-posts?context=article-related [https://perma.cc/UGZ6-W2D4].

${ }^{398}$ Ari Natter, Trump to Nominate Former House Staffer for Top Environment Job, BLOOMBERG DAILY ENV'TREP. (June 14, 2018), https://news.bloombergenvironment.com/environ ment-and-energy/trump-to-nominate-former-house-staffer-for-top-environment-job/ [https:// 
she had worked on the 2011 legislation to exclude GHGs from regulation under the CAA. ${ }^{399}$ She is expected to be confirmed, but as of August 2018 this has not occurred. ${ }^{400}$ It is expected that the CEQ will continue working to revise NEPA's implementing regulations. ${ }^{401}$ While nearly all knowledgeable people believe climate change is an existential threat, the President and nearly all of his political appointees do not.

The federal government continues to work to prevent the use and dissemination of information that could support efforts to limit and adapt to climate change. On April 28, 2017, EPA removed from its website over 200 pages of information on climate change titled "Climate and Energy Resources for State, Local and Tribal Governments." ${ }^{402}$ Three months later, a new website focused on energy was added. ${ }^{403}$ Documents obtained by the Environmental Defense Fund's Freedom of Information Act request show that former Administrator Pruitt and his political appointees were personally involved in removing material related to climate change. ${ }^{404}$

On October 31, 2017, former Administrator Pruitt issued a directive "Strengthening and Improving Membership on EPA Federal Advisory Committees." ${ }^{\circ 05}$ The directive bars membership on EPA advisory committees for

perma.cc/3G4Q-5EQ2]; Brady Dennis \& Juliet Eilperin, White House withdraws controversial nominee to head Council on Environmental Quality, WASHINGTON PosT (Feb. 4, 2018), https://www.washingtonpost.com/news/energy-environment/wp/2018/02/03/white -house-to-withdraw-controversial-nominee-to-head-council-on-environmental-quality/?no redirect=on\&utm_term=.1e226e1dc1e3 [https://perma.cc/TE2C-VQ3M].

${ }^{399}$ Trump Taps Acting White House CEQ Chair Neumayr For Permanent Role, INSIDE EPA (June 28, 2018), https://insideepa.com/daily-feed/trump-taps-acting-ceq-chair-perma nent-role [https://perma.cc/XST9-AKRD].

${ }^{400}$ Abby Smith, Trump Pick for Environment Council Faces Easier Confirmation Path, BLOOMBERG DAILY ENV'T REP. (June 15, 2018), https://news.bloombergenvironment.com lenvironment-and-energy/trump-pick-for-environment-council-faces-easier-confirmation -path/ [https://perma.cc/5W2G-XTC2].

${ }^{401}$ Alan Kovski, White House Weighs Long-Sought Environmental Review Changes, BLOOMBERG ENV'T REP. (June 19, 2018), https://news.bloombergenvironment.com/environment -and-energy/white-house-weighs-long-sought-environmental-review-changes [https://perma .cc/E23P-PZ3L].

${ }^{402}$ Senate Democrats Ask Pruitt To Restore Missing EPA Climate Web Pages, InsIDEEPA (Nov. 16, 2017), https://insideepa.com/daily-feed/senate-democrats-ask-pruitt-restore-epa -climate-web-pages [https://perma.cc/Q9FX-8CQQ].

${ }^{403}$ Lee Logan, Trump EPA Removes 'Climate' References From Its State Energy Website, INSIDEEPA (Nov. 2, 2017), https://insideepaclimate.com/daily-news/trump-epa-removes -climate-references-its-state-energy-website [https://perma.cc/3TJD-JJM6].

${ }^{404}$ Michael Biesecker, Pruitt monitored removal of climate data from EPA webpages, emails show, PBS (Feb. 2, 2018), https://www.pbs.org/newshour/politics/emails-show-pruitt-moni tored-changes-to-epa-webpages-on-climate [https://perma.cc/W67F-HLP6].

${ }^{405}$ Scott Pruitt, Strengthening \& Improving Membership on EPA Federal Advisory 
anyone currently receiving an EPA grant. ${ }^{406}$ It applies primarily to academics, but does not apply to state, tribal, or local government agencies. ${ }^{407} \mathrm{On}$ November 3, 2017, EPA released a list of new appointees that primarily includes state and industry employees. ${ }^{408}$ The Union of Concerned Scientists has documented the Trump administration's attack on science in more detail ${ }^{409}$ In President Trump's 2019 budget proposal, released February 12, 2018, he proposed to eliminate or seriously reduce funding for numerous scientific and diplomatic efforts by EPA to study or address climate change. ${ }^{410}$

\section{CONCLUSION}

NEPA was enacted in 1970 , about twenty years prior to the time that GHG emissions and climate change began to be a concern of the environmental community. ${ }^{411}$ The regulations and court cases that shaped the development of environmental laws, including NEPA, were concerned with conventional pollutants and traditional natural resources issues. As GHG emissions and climate change issues developed, they became part of the NEPA review process. ${ }^{412}$ Under NEPA, the legal issues that became most important were the need to consider alternatives and the extent to which cumulative effects needed to be addressed for specific projects. ${ }^{413}$ This resulted in inconsistent agency reviews of climate change effects because the coverage required was largely left to agency discretion. ${ }^{414}$

Judicial review of NEPA-based analyses of climate change issues rarely occurs. The costs of litigation and the fact that NEPA only requires

Committees, EPA(Oct. 31, 2017), https://www.epa.gov/faca/strengthening-and-improving -membership-epa-federal-advisory-committees [https://perma.cc/PR52-LAUT].

${ }^{406} I d$.

${ }^{407} \mathrm{Id}$.

${ }^{408}$ Maria Hegstad, Critics Float Legal Theories To Challenge Scott Pruitt's Science Adviser Policy, 24 RISK POL'Y REP. (Inside EPA) 44 (Nov. 7, 2017), http://columbiaclimatelaw.com /files/2017/11/Columbia-Law-School-Critics-Float-Legal-Theories-Risk-11-17.pdf [https:// perma.cc/TK6L-YRC9].

${ }^{409}$ UNION OF CONCERNED SCIENTISTS, Sidelining Science Since Day One (July 2017), http:// www.ucsusa.org/sideliningscience [https://perma.cc/S85P-8RBM] (last visited Nov. 17, 2018). ${ }^{410}$ Jennifer A. Diouhy et al., Trump Puts Energy Savings, Climate Plans on Chopping Block Again, BLOOMBERG DAILY ENV'T REP. (Feb. 12, 2018), https://www.sfchronicle.com /news/article/Trump-puts-energy-saving-climate-plans-on-12607706.php [https://perma .cc/6EXN-6ZS3].

${ }^{411}$ NEPA, 42 U.S.C. $\S \S 4331-4370$ h (2017).

${ }^{412}$ Final Guidance, supra note 53, at 3844.

${ }^{413} 40$ C.F.R. $\S 1508.9$ (b).

${ }^{414}$ NEPA, 42 U.S.C. $§ 4331$ at 4333 (2017). 
procedural compliance discourages challenges. Moreover, courts are usually deferential to agency judgment calls. Nevertheless, NEPA has served a useful function in broadening agency perspectives. Its success over the years was aided by a bipartisan concern that federal agency decisions should take environmental values into consideration. That changed in recent years, as the nation's political parties moved to more extreme positions. Environmental laws have often been the scapegoat for problems generated by globalization and population growth. At the same time, the massive influx of money into the political process has isolated both political parties from the need to be concerned for their constituents. The ability of corporations and billionaires to control the political process has led to facts being unimportant, and truth is whatever the interest group with the most money wants it to be. Environmental protection has become a casualty. For NEPA to be effective, it requires good faith leadership of the federal agencies by those with both competence and a desire to achieve their agency's mission while balancing broader considerations including environmental protection. Unfortunately, the agencies charged with environmental, energy, and natural resource protection are headed by executives with an agenda at variance with the goals of NEPA. Until that changes, the weaknesses of the NEPA process will make it a tool of limited value in adapting to climate change. 